\title{
Molecular regulation of spermatogonial stem cell renewal and differentiation
}

\author{
Juho-Antti Mäkelä${ }^{1}$ and Robin M Hobbs²,3 \\ ${ }^{1}$ Research Centre for Integrative Physiology and Pharmacology, Institute of Biomedicine, University of Turku, Turku, \\ Finland, ${ }^{2}$ Australian Regenerative Medicine Institute, Monash University, Melbourne, Victoria, Australia and \\ ${ }^{3}$ Development and Stem Cells Program, Monash Biomedicine Discovery Institute and Department of Anatomy and \\ Developmental Biology, Monash University, Melbourne, Victoria, Australia
}

Correspondence should be addressed to J-A Mäkelä; Email: juho-antti.makela@utu.fi

\begin{abstract}
The intricate molecular and cellular interactions between spermatogonial stem cells (SSCs) and their cognate niche form the basis for life-long sperm production. To maintain long-term fertility and sustain sufficiently high levels of spermatogenesis, a delicate balance needs to prevail between the different niche factors that control cell fate decisions of SSCs by promoting self-renewal, differentiation priming or spermatogenic commitment of undifferentiated spermatogonia $\left(A_{\text {undiff }}\right)$. Previously the SSC niche was thought to be formed primarily by Sertoli cells. However, recent research has indicated that many distinct cell types within the testis contribute to the SSC niche including most somatic cell populations and differentiating germ cells. Moreover, postnatal testis development involves maturation of somatic supporting cell populations and onset of cyclic function of the seminiferous epithelium. The stochastic and flexible behavior of $A_{\text {undiff }}$ further complicates the definition of the SSC niche. Unlike in invertebrate species, providing a simple anatomical description of the SSC niche in the mouse is therefore challenging. Rather, the niche needs to be understood as a dynamic system that is able to serve the long-term reproductive function and maintenance of fertility both under steady-state and during development plus regeneration. Recent data from us and others have also shown that $A_{\text {undiff }}$ reversibly transition between differentiation-primed and self-renewing states based on availability of niche-derived cues. This review focuses on defining the current understanding of the SSC niche and the elements involved in its regulation.

Reproduction (2019) 158 R169-R187
\end{abstract}

\section{Introduction}

Maintenance of adult tissues often depends on a resident stem cell population that is able to both self-renew and produce differentiating progeny in a limitless fashion. Stem cell potential in the mouse testis is restricted to a population of A-type undifferentiated spermatogonia or $A_{\text {undiff. }}$. However, under steady-state conditions most $A_{\text {undiff }}$ are primed for spermatogenic differentiation and only a small subset undergoes self-renewal (Fig. 1). Whether stemness in the male germline is a characteristic of a subset of isolated single cells $\left(A_{s}\right)$ or a property shared by most $\mathrm{A}_{\text {undiff }}$ is heatedly debated (de Rooij 2017, Lord \& Oatley 2017). While traditional models propose that stem cell capacity is restricted to $\mathrm{A}_{\mathrm{s}}$ spermatogonia (Lord \& Oatley 2017), the majority of current data support a dynamic stem cell model in which fate of $A_{\text {undiff }}$ cells is context-dependent and plastic (Hara et al. 2014, Carrieri et al. 2017, Garbuzov et al. 2018, Hermann et al. 2018, La et al. 2018b). Lineage-tracing studies and mathematical modeling support stochastic stem cell behavior in vivo, while in vitro data demonstrate the seminal role of niche-derived cues in the regulation of A $_{\text {undiff }}$ fate.

The spermatogonial stem cell (SSC) niche in the mammalian testis is considered an open niche that cannot be precisely anatomically defined. Due to cyclical fluctuations in the expression of paracrine regulators, the SSC niche changes its nature over the course of the seminiferous epithelial cycle. Thus, the SSC niche is likely defined by molecular, not anatomical, criteria and a microenvironment that enables and promotes SSC self-renewal at the expense of differentiation priming, constitutes the minimal criteria for a SSC niche.

Development of an in vitro culture system for $\mathrm{A}_{\text {undiff }}$ has considerably advanced research on male germline stem cells (Kanatsu-Shinohara et al. 2003, Kubota et al. 2004). Cultured $A_{\text {undiff }}$ can be expanded essentially indefinitely, while retaining their self-renewal capacity and the capability to give rise to long-term spermatogenic colonies when transplanted to a germ cell-depleted testis. While this has enabled the effect of a number of candidate molecules on $\mathrm{A}_{\text {undiff }}$ physiology to be assessed, it has also introduced an unappreciated dilemma: 


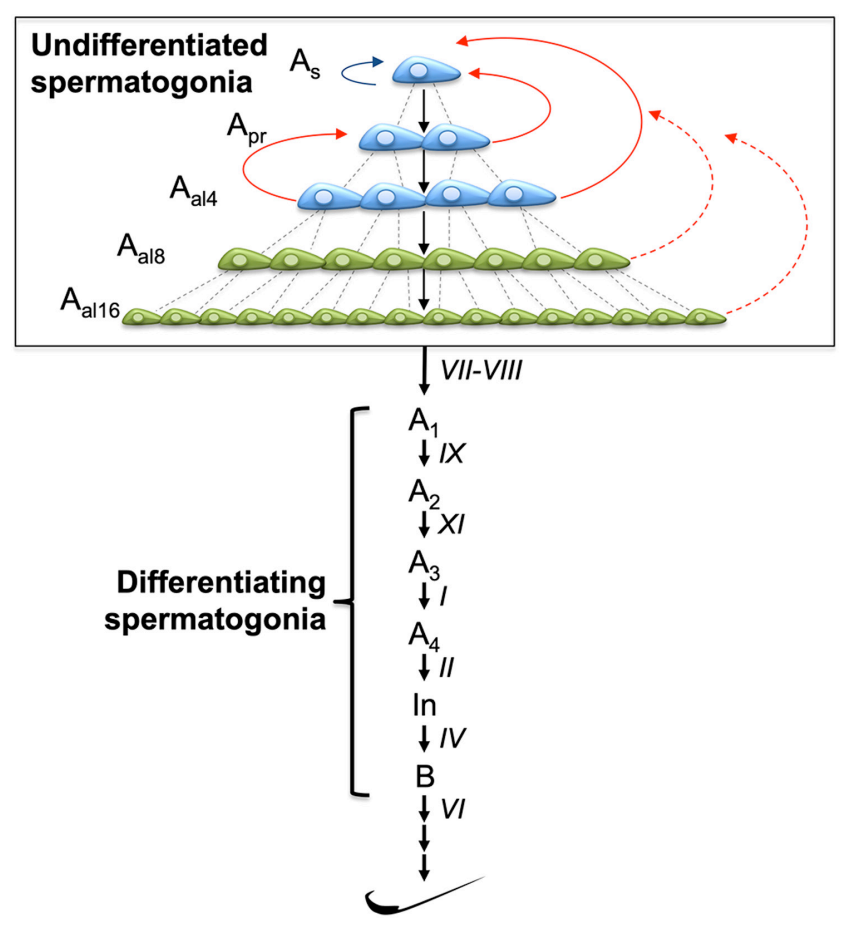

Figure $1 \mathrm{Germ}$ cell expansion and kinetics in the mouse testis. The pool of undifferentiated spermatogonia, $A_{\text {undiff, }}$ is composed of isolated single cells $\left(A_{s}\right)$, and syncytia of typically $2\left(A_{p r}\right), 4\left(A_{a l 4}\right), 8$ $\left(\mathrm{A}_{\mathrm{al} 8}\right)$ or $16\left(\mathrm{~A}_{\mathrm{al16}}\right)$ interconnected cells. There are two models to describe stemness within the male germline: a revised $A_{s}$ model (blue curved arrow) proposes self-renewal capacity to lie primarily within a subset of $A_{s}$ spermatogonia, while the fragmentation model suggests that cytokinesis in the male germline is typically incomplete and the population of $A_{s}$ spermatogonia is maintained by fragmentation of short syncytia (red curved arrows). According to the fragmentation model, longer syncytia rarely fragment under homeostatic conditions (red curved, dashed arrows) but do so readily upon germline damage and induction of a regenerative response. A subset of $\mathrm{A}_{\text {undiff }}$ commits to spermatogenesis at stage VII-VIII of the seminiferous epithelial cycle. The mitoses of differentiating spermatogonia (type A1, A2, A3, $\mathrm{A} 4$, In and B) are dictated by the progress of the seminiferous epithelial cycle, whereas $A_{\text {undiff }}$ divide in a random fashion, although typically only in stages $\mathrm{X}$-II. Type B spermatogonia give rise to meiotic spermatocytes that ultimately produce sperm.

most $A_{\text {undiff }}$ in standard cultures have progenitor-like characteristics, and cells, that display a transcriptomic signature typical of the in vivo self-renewing state, form a minority (La et al. 2018b). This is because robust expansion of $A_{\text {undiff }}$ is typically preferred but the means to monitor the composition of the culture (i.e., ratio of stem vs progenitor-like cells) have been very limited until recently (La et al. 2018b).

According to current knowledge, multiple cell types can contribute to the regulation of SSC self-renewal and differentiation. While Sertoli cells likely represent the most important of these, recent research has expanded the components of the SSC niche to include a number of somatic cell types plus different cohorts of spermatogenic cells, whose significance for the paracrine regulation of spermatogenesis is increasingly appreciated (Griswold 2016, Potter \& DeFalco 2017, Mäkelä \& Toppari 2018a). This review provides an overview of the composition and regulation of the SSC niche in mouse. To highlight its dynamic nature, the effects of somatic maturation, aging, cyclical function of the seminiferous epithelium and regenerative conditions on the niche are also discussed.

\section{Kinetics of mouse undifferentiated spermatogonia}

SSCs constitute a subset of $A_{\text {undiff }}$ that are present on the basement membrane of the seminiferous epithelium. $A_{\text {undiff }}$ in the mouse are found as single cells (A-single or $A_{s}$ spermatogonia) or as syncytia of typically 2, 4, 8 and 16 cells interconnected by cytoplasmic bridges (A-paired, $\mathrm{A}_{\mathrm{pr}}$ and A-aligned, $\mathrm{A}_{\mathrm{al} 4-16}$ ) (Mäkelä \& Toppari 2018b). Odd-numbered syncytia (mainly $A_{a \mid 3}$ ), that are observed at a low frequency, are thought to originate from fragmentation of longer syncytia, especially $A_{a 14}$ (Hara et al. 2014). According to the 'dynamic SSC model' (discussed in more detail below), this same mechanism is responsible for replenishing the pool of $A_{s}$, since the progeny of their division are normally connected by a cytoplasmic bridge $\left(A_{p r}\right)$ (Hara et al. 2014), whereas a 'revised $A_{s}$ model' proposes that $A_{s}$ maintain their numbers by undergoing complete cytokinesis (Lord \& Oatley 2017). A subset of $A_{\text {undiff }}$ irreversibly commits to spermatogenesis at a specific stage of the seminiferous epithelial cycle, and the mitoses of differentiating spermatogonia, unlike those of $\mathrm{A}_{\text {undiff, }}$ are dictated by the progress of the spermatogenic program (Tegelenbosch \& de Rooij 1993, Mäkelä \& Toppari 2018a) (Fig. 1).

Stemness within the mouse undifferentiated spermatogonial population is considered inversely proportional to syncytial length. Thus, $A_{s}$ cells were traditionally regarded as the actual stem cells, whereas $A_{p r}$ and $A_{a l}$ were thought to represent transit-amplifying progenitors(de Rooij 2017). However, with the advent of new experimental tools and molecular markers, it became apparent that $A_{\text {undiff }}$ hierarchy is more complex than originally proposed and $A_{s}$ can directly commit to differentiate without prior amplification (Nakagawa et al. 2010, Hara et al. 2014). Furthermore, syncytial fragmentation has been proposed to guarantee that probably any cell within an undifferentiated syncytium can re-enter the $\mathrm{A}_{\mathrm{s}}$ state in an appropriate environment (Hara et al. 2014). Therefore stemness within the $A_{\text {undiff }}$ population is potentially a shared feature of the entire population, and the continuous cycling between equipotent single and short syncytial states is a mechanism that both maintains stemness and provides a sufficiently high number of differentiationprimed progeny to enter spermatogenesis at a specific stage of the seminiferous epithelial cycle (Hara et al. 2014). Notably, an alternative model to accommodate traditional views and recent progress on the field has also been proposed (Lord \& Oatley 2017). 
Over the years, there has been numerous efforts to further dissect the $A_{s}$ population into functional categories (active stem cells, reserve stem cells, ultimate stem cells, the most primitive stem cells and so forth) and the quest to identify and isolate these cells is still ongoing. A number of molecular markers that identify these distinct $A_{s}$ populations have been proposed (PAX7, ID4, BMI1, NANOG and ERBB3) but none are generally accepted to identify specific subsets of SSCs or $A_{s}$ spermatogonia (Ventelä et al. 2012b, Abid et al. 2014, Aloisio et al. 2014, Chan et al. 2014, Komai et al. 2014).

\section{Undifferentiated male germ cells}

Given a lack of definitive SSC markers, the stem cell nature of a germ cell can only be estimated retrospectively by assessing its ability to give rise to long-term spermatogenesis following transplantation to an infertile recipient (Brinster \& Zimmermann 1994). It is evident that most $A_{\text {undiff }}$ of the mouse testis are primed for differentiation and display only latent self-renewal capacity (Nakagawa et al. 2007, Nakagawa et al. 2010, Hara et al. 2014). Importantly, the experimental conditions for transplanted cells to demonstrate their SSC nature are somewhat unphysiological, as the transplantation procedure presumably inflicts unusual stress on the cells, and SSCs under steady state are not expected to translocate from the tubular lumen to the basement membrane of the seminiferous epithelium. Consequently, the homing efficiency of SSCs is estimated to be approx. $10 \%$, although precise efficiencies in many contexts are undefined (Nagano et al. 1999, Nagano 2003). The ability of transplanted cells to engraft and generate spermatogenic colonies is thus unlikely to provide a perfect measure of stem cell capacity.

Contrasting views on SSC identity and $\mathrm{A}_{\text {undiff }}$ hierarchy have been proposed. The $A_{\text {undiff }}$ compartment of the mouse testis can be envisaged as a continuum of dynamic interconvertible cell states with progressively declining self-renewal capacity or likelihood (Nakagawa et al. 2007, Nakagawa et al. 2010, Hara et al. 2014, La et al. 2018b). It is also proposed that SSCs comprise a small subset of $A_{s}$, although evidence for the existence of these 'ultimate SSCs' remains limited (de Rooij 2017, Lord \& Oatley 2017). Potentially, the behavior of an undifferentiated spermatogonium may solely be determined by the microenvironment, i.e. the niche, where it is found (Nakagawa et al. 2010, La et al. 2018b). Self-renewal ability of male germline stem cells would thus not solely be an inherent property of the cell but profoundly affected by the microenvironment. This notion is supported by the ability of differentiationprimed $\mathrm{A}_{\text {undiff }}$ to generate long-lived spermatogenic colonies in infertile recipients and indicates that the number of cells capable of functioning as stem cells within the testis is considerably higher than the number of actual stem cells (Nakagawa et al. 2010, Carrieri et al.
2017, La et al. 2018b). Our recent data further show that cultured $\mathrm{A}_{\text {undiff }}$ readily interconvert between stem and progenitor states based on the availability of niche factor GDNF (glial cell line-derived neurotrophic factor), and the environmental permissiveness thus defines the state (stem/progenitor) of an $\mathrm{A}_{\text {undiff }}$ (La et al. 2018b).

To further complicate the assessment of stemness within the male germline, we have to consider the use of this term in different contexts. As previously highlighted, male germline stem cells have been assigned a number of tasks: maintenance of homeostasis, regeneration of tissue after injury and ability to restore spermatogenesis after transplantation into an infertile recipient (Yoshida 2012). Whether there are different subsets of $A_{\text {undiff }}$ for different tasks awaits clarification. This would, however, be a rather complicated scenario. In our opinion it is more likely that in-built heterogeneity existing within the $A_{\text {undiff }}$ population combined with their flexible and stochastic behavior safeguards male germline maintenance both under steady-state conditions and after tissue damage (Nakagawa et al. 2007, Nakagawa et al. 2010, Hara et al. 2014, Carrieri et al. 2017, Garbuzov et al. 2018, La et al. 2018b).

Evidence for a 'revised $A_{s}$ model' comes from histological studies and more recent research performed in Jon Oatley's group utilizing an Id4-eGFP transgene to delineate the self-renewing subset within $A_{\text {undiff }}$. (Fig. 2) (Lord \& Oatley 2017). The model proposes that stemness within the $A_{\text {undiff }}$ population is arranged in a strict hierarchy, and only a subset of $A_{s}$ spermatogonia $\left(\mathrm{SSC}_{\text {ultimate }}\right)$ is capable of self-renewal and marked by high levels of $I d 4$ expression. While the model supports that some plasticity may exist for $\mathrm{A}_{\text {undiff }}$ at the early phase of transition from $\mathrm{SSC}_{\text {ultimate }}$ to progenitor state (i.e. SSC $_{\text {transitory }}$ ), it argues against reversion of cell fate from progenitor states to the stem cell pool or fragmentation of $A_{\text {undiff }}$ syncytia - two fundamental concepts of the 'dynamic SSC model'. Oatley and colleagues have demonstrated that the Id4-eGFPbright $\mathrm{A}_{\text {undiff }}$ population is highly enriched for SSC activity. However, conclusions from these studies suffer some limitations due to (1) use of early postnatal mice where the niche and SSCs themselves are different from the adult counterparts (Ernst et al. 2019) and (2) flow cytometric-based sorting of cells for transplantation studies compared activity of Id4-eGFPbright versus Id4-eGFPdim populations but functional capabilities and identity of an abundant population expressing intermediate levels of the $I d 4$ reporter were not characterized (Chan et al. 2014, Helsel et al. 2017). Moreover, recent independent assessments of Id4 expression by single-cell RNA sequencing, immunostainings and use of independent mouse reporter lines have demonstrated that $I d 4$ expression is substantially more widespread within the $\mathrm{A}_{\text {undiff }}$ (or male germline in general) than previously described (Hermann et al. 2018, La et al. 2018a, Kitadate et al. 2019, La et al. 2018b). Notably, in the adult testis, Id4 expression 


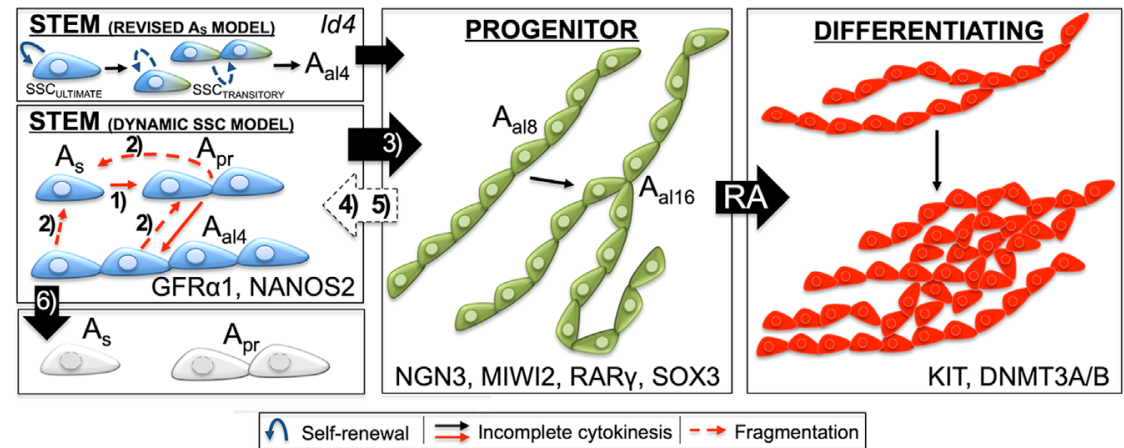

Figure 2 Dynamics of $A_{u n d i f f}$ in the adult mouse testis. According to a 'revised $A_{s}$ model', stem cell capacity in the male germline is restricted to a subset of $A_{s}$ spermatogonia, i.e. SSC $_{\text {ultimate }}$. These cells both maintain their own population (self-renewal; curved arrow) and give rise to cells ( $A_{s}$ and $\mathrm{A}_{\mathrm{pr}}$ ) in transit to the progenitor state, i.e. SSC $_{\text {transitory }}$ that possess limited capability for self-renewal. Reversion of cell fate from a progenitor to stem state is strictly not possible under any conditions. As an alternative, a 'dynamic SSC model' proposes that (1) cytokinesis (solid arrow) of male germ cells is incomplete, and also the progeny of $A_{s}$ division $\left(A_{p r}\right)$ is connected by a cytoplasmic bridge. (2) GFR $1 /$ NANOS2-positive $\mathrm{A}_{\text {undiff }}$ continuously interconvert between equipotent single-cell and short syncytial states via fragmentation (dashed arrow) and incomplete cytokinesis (solid arrow). (3) GFR 1 1/NANOS2-positive $\mathrm{A}_{\text {undiff }}$ also give rise to NGN3/MIWI2-positive progenitor cells that undergo differentiation priming. (4) Under steady-state conditions NGN3-positive $A_{\text {undiff }}$ do not typically revert back to the self-renewing state. (5) In regenerative conditions, however, NGN3/MIWI2-positive $\mathrm{A}_{\text {undiff }}$ readily contribute to the long-lived stem cell population via reversion of characteristic gene expression patterns. (6) If an SSC niche is depleted of stem cell(s), cell migration from neighboring niches safeguards the long-term spermatogenic function. RA induces the irreversible differentiation commitment in the germline. The color key used for different cell types is used throughout this article.

displays limited enrichment in $\mathrm{A}_{\text {undiff }}$ fractions endowed with the highest SSC capacity (Garbuzov et al. 2018, La et al. 2018b). The validity of this model therefore awaits confirmation from other groups.

Support for a 'dynamic SSC model' is derived from studies where distinct reporter mouse lines are used in conjunction with intravital imaging, lineage tracing and computational analysis. These techniques have enabled monitoring of the fate of individual undifferentiated spermatogonia over the course of several days or months, and these experiments have given answers to many long-standing questions in the field of germline stem cell biology. These include (Fig. 2):

1. $A_{s}$ division is (almost) always incomplete and results in the formation of $A_{p r}$ (Hara et al. 2014)

2. The population of $A_{s}$ spermatogonia is maintained by fragmentation of short syncytia, although the underlying regulatory mechanisms are thus far unknown (Nakagawa et al. 2010, Hara et al. 2014)

3. NANOS2/GFR $\alpha 1$-positive (GDNF family receptor alpha 1) undifferentiated spermatogonia constitute the steady-state SSC population (Sada et al. 2009, Nakagawa et al. 2010, Hara et al. 2014)

4. Differentiation-primed NGN3/MIWI2-positive (neurogenin 3/PIWIL4) progenitors rarely contribute to the long-term stem cell population in undisturbed tissue (Nakagawa et al. 2007, Nakagawa et al. 2010, Hara et al. 2014, Carrieri et al. 2017)

5. Under regenerative conditions NGN3/MIWI2positive cells, however, can revert back to the GFR $\alpha 1$-positive stem cell state and form long-term spermatogenic colonies (Nakagawa et al. 2010, Hara et al. 2014, Carrieri et al. 2017)

6. There is an active turnover within the stem cell compartment and over the course of time, stem cells are stochastically lost via differentiation and replenished by cell migration from neighboring niches (Klein et al. 2010, Hara et al. 2014)

These findings form the basis of a 'dynamic SSC model' developed from the studies of Shosei Yoshida's lab and supported by work from independent groups (Hara et al. 2014, Carrieri et al. 2017, Garbuzov et al. 2018, La et al. 2018b). According to this model $A_{\text {undiff }}$ fate is plastic and context dependent emphasizing the role of environmental cues in defining the $A_{\text {undiff }}$ state. Despite obvious merit, the model is far from complete, and mechanisms regulating fragmentation of $\mathrm{A}_{\text {undiff }}$ syncytia, an integral component of this model, are essentially undefined.

Under steady-state conditions it can be argued that the differences between these two models are rather insignificant and primarily dispute the mechanism for maintenance of the $A_{s}$ population, i.e. complete cytokinesis vs syncytial fragmentation, while both models claim that all (Oatley) or most (Yoshida) SSC capacity is restricted to $A_{s}$ and $A_{p r}$ spermatogonia. However, under regenerative conditions, the differences become more fundamental in nature as the Oatley model argues against the possibility of differentiation-primed progenitors being able to contribute to the long-lived stem cell pool in contrast to the Yoshida model. 


\section{SSCs niche}

\section{SSC density}

Similar to stem cells present in other adult tissues, SSCs might be predicted to localize preferentially to restricted regions within the tubules that contain an environment supportive of self-renewal (the niche). Despite displaying a preferential localization to tubular areas bordering the interstitial tissue and vasculature (Chiarini-Garcia et al. 2001, Chiarini-Garcia et al. 2003, Yoshida et al. 2007, Hara et al. 2014), $\mathrm{A}_{\text {undiff }}$ are rather uniformly distributed on the basement membrane of mouse seminiferous epithelium and have not been found to accumulate to any substantial degree in specific regions in undisturbed WT testis (see below). As recently demonstrated by Kitadate et al. (2019), competition for limited levels of FGFs secreted by lymphatic endothelial cells (LECs) associated with vasculature and the interstitium regulates density and size of the SSC population within the tubule basal layer (Kitadate et al. 2019). Specifically, SSC selfrenewal and proliferation are favored at areas of high FGF concentration, that is vasculature- and interstitiumproximal regions, and SSCs need to be exposed to a sufficiently high FGF stimulus in order to maintain the self-renewing state. Spatially restricted availability of FGFs forces - and innate motile behavior enables - SSCs to compete with each other for consumption of FGF. SSCs that receive more FGF become biased toward selfrenewal over differentiation, and a mechanism based on limited availability and competition for FGFs thus plays a key role in regulation of SSC density (Kitadate et al. 2019).

\section{Vasculature-associated niche}

Unlike in many invertebrate species, the mouse SSCs niche cannot be precisely defined solely by anatomical criteria. Undifferentiated spermatogonia are, however, typically found on the basement membrane at an area that is adjacent to interstitial tissue and vasculature (Chiarini-Garcia et al. 2001, Chiarini-Garcia et al. 2003, Yoshida et al. 2007). Moreover, live-cell imaging studies have demonstrated that GFR 1-positive spermatogonia actively move within or between these vasculature-proximal regions, and alteration of the vasculature pattern around the tubule perimeter results in rearrangement of undifferentiated spermatogonia to the proximity of blood vessels (Yoshida et al. 2007, Hara et al. 2014). The movement of GFR 1 1-positive spermatogonia within the basal compartment is arguably important for quantitatively normal spermatogenesis because stochastic emptying of the niche is a common feature of mouse spermatogenesis (Klein et al. 2010, Hara et al. 2014). Were the empty niches not occupied by new stem cells, the number of spermatogenic units would inevitably decrease resulting in reduced sperm production over time. It is not known if the movement of GFR $\alpha 1$-positive $A_{\text {undiff }}$ follows a chemotactic gradient (such as GDNF) or if some other mechanism drives their displacement (Hara et al. 2014). Interestingly, GDNF has been shown to function as a chemoattractant for freshly isolated $\mathrm{A}_{\text {undiff, }}$ and it could therefore stimulate chemotactic movement of SSCs to areas of high GDNF concentration, i.e. an SSC niche (Kanatsu-Shinohara et al. 2012, Dovere et al. 2013). Upon differentiation, spermatogonia lose preference for these areas and become dispersed throughout the basal compartment of the seminiferous epithelium.

There are at least three obvious explanations for the preferred localization of GFR $\alpha 1$-positive $A_{\text {undiff }}$ to vasculature-proximal regions:

- SSCs depend on (a) blood-borne compound(s)

- SSCs depend on (a) factor(s) that is/are derived from vasculature-associated somatic cells (primarily vascular endothelial cells or Leydig cells)

- SSCs depend on the somatic paracrine milieu near the vasculature, that is influenced by endocrine factors carried to the testis by blood stream, and thus found at the highest level at these areas

There is evidence to support the latter two, and while many factors found in blood plasma are crucial for spermatogenesis (such as, FSH and LH (for a review see Mäkelä \& Toppari 2017; Mäkelä \& Toppari 2017)), they may not directly act on SSCs. According to recent data the biased localization of SSCs toward the vasculature and surrounding interstitium can be explained by the unique paracrine milieu found within these testicular zones. Bhang et al. (2018) and Kitadate et al. (2019) identified testicular endothelial cells (TECs) and LECs, respectively, as critical sources of factors supporting SSCs, thus providing an explanation for the enrichment of SSCs at longitudinal areas in proximity of the vasculature (Bhang et al. 2018, Kitadate et al. 2019). The SSC niche may be understood as an entity to which numerous different somatic and germ cell types contribute (Box 1 and Fig. 3). Since postnatal testis development encompasses maturation of somatic cell types and appearance of meiotic and post-meiotic germ cells, the SSC niche in the adult mouse is understandably different from the one found in juvenile mice. For instance, Sertoli cells of juvenile mice are functionally immature and during the first month of postnatal life they undergo maturation that encompasses profound changes in their transcriptome, function and structure (Mäkelä \& Toppari 2017). Furthermore, due to cyclical fluctuations in the expression of paracrine regulators, the SSC niche changes its nature in the adult over the course of the seminiferous epithelial cycle (Mäkelä \& Toppari 2018a). 


\section{Box 1: Cell types contributing to the SSC niche}

\section{Sertoli cells}

Sertoli cells are the guardians of the germline, and support, nurture and protect germ cells in numerous ways (for a review see Franca et al. 2016; Franca et al. 2016 and references therein). SSCs (like all other germ cells) are in direct contact with Sertoli cells, and lack of a report describing a germ cell-only tubular phenotype implies that SSCs and more advanced germ cells cannot exist without Sertoli cells in vivo. Sertoli cells secrete numerous paracrine factors that act specifically on $\mathrm{A}_{\text {undiff' }}$ most notably GDNF (Meng et al. 2000).

\section{Peritubular myoid cells}

Seminiferous tubules are encased by contractile smooth muscle cells called peritubular myoid cells (PMCs). Besides providing structural support and propelling the flow of luminal fluid toward the rete testis, PMCs also secrete paracrine factors important for SSCs, including GDNF (Chen et al. 2014).

\section{Peritubular macrophages}

Tissue-resident macrophages are often neglected in everyday testis research. This is especially true for peritubular macrophages, a cell population that went completely unnoticed until 2015 (DeFalco et al. 2015). While the specific physiological role for these cells still warrants future studies, the available data suggest that they may take part in control of SSC maintenance and differentiation (for a review see Potter \& DeFalco (2017); Potter \& DeFalco 2017).

\section{Testicular endothelial cells}

TECs are a rich source of cytokines implicated in stem cell biology, including GDNF. As recently demonstrated by Bhang et al. (2018), TECs are able to support SSCs in vitro without exogenous GDNF, and TEC-derived factors significantly promote the repopulation of the seminiferous epithelium after a cytotoxic insult (Bhang et al. 2018). These data suggest that TECs are a key component of the SSC niche.

\section{Leydig cells}

Leydig cell-derived testosterone is a master paracrine factor in the testis. While testosterone is strictly indispensable for spermatogenesis, under normal conditions, it regulates the expression of thousands of genes in different somatic cell populations in the testis (O'Hara \& Smith 2015, Oduwole et al. 2018). Some of these then act on SSCs. Besides testosterone, Leydig cells also produce factors that directly target SSCs (Huang et al. 2009, Oatley et al. 2009, Wang et al. 2015).

\section{Lymphatic endothelial cells}

LECs are found at the border of seminiferous tubules and testicular interstitium and cover the surface of the lymphatic space. LECs in proximity to vasculature express a number of FGFs (FGF4, 5 and 8), which were shown to regulate the density of GFR $\alpha 1$-positive $A_{\text {undiff }}$ (Kitadate et al. 2019). Through production of FGFs, LECs act as key regulators of SSC population size.

\section{Germ cells}

The onset of spermatogenesis soon after birth brings another layer of complexity to the paracrine milieu of the testis, because germ cells, besides expressing receptors for soma-derived factors, can also generate soluble factors. Cyclical progression of the seminiferous epithelium guarantees appearance of specific germ cell subpopulations after fixed intervals providing a coordinated and efficient control mechanism for cell fate decisions within the seminiferous epithelium, such as onset of differentiation (Mäkelä \& Toppari 2018a).

\section{Establishment of the SSC niche}

SSCs are specified perinatally as the population of fetal germ cells known as gonocytes or prospermatogonia migrates from the lumen of testis cords to the basement membrane. A subset of gonocytes contributes to the first wave of spermatogenesis, whereas the rest form the pool of SSCs (Mäkelä et al. 2019). SSCs then actively proliferate to expand the population (Nagano et al. 2000). This coincides with a period of high Gdnf expression, and GDNF has been suggested to stimulate SSC proliferation in the early postnatal testis (Naughton et al. 2006, Pui \& Saga 2017). Besides maintaining active divisions of SSCs, the specific microenvironment of the developing juvenile seminiferous tubule also provides a relatively high number of niches for the mitotic progeny of SSCs (Shinohara et al. 2001, Kitadate et al. 2019).
Probably as an outcome of somatic cell maturation and establishment of hypothalamus-pituitary-testis axis, this microenvironment changes and the number of accessible niches diminishes during the course of development (Shinohara et al. 2001). Importantly, not only is the niche different, but also the SSCs of pup and adult mice differ and SSCs from pup testis lean toward differentiation at the expense of self-renewal (Ebata et al. 2007). The adult-type SSC niche is characterized by considerably lower, yet still readily detectable, levels of GDNF which is partially under endocrine control, and also regulated by the cycle of the seminiferous epithelium (Tadokoro et al. 2002, Grasso et al. 2012, Ventelä et al. 2012a, Tokue et al. 2017, Sharma \& Braun 2018). Interestingly, Gdnf is upregulated in regenerating testis after loss of most differentiating spermatogonia and a substantial subset of $A_{\text {undiff' }}$ suggesting that a juvenile- 


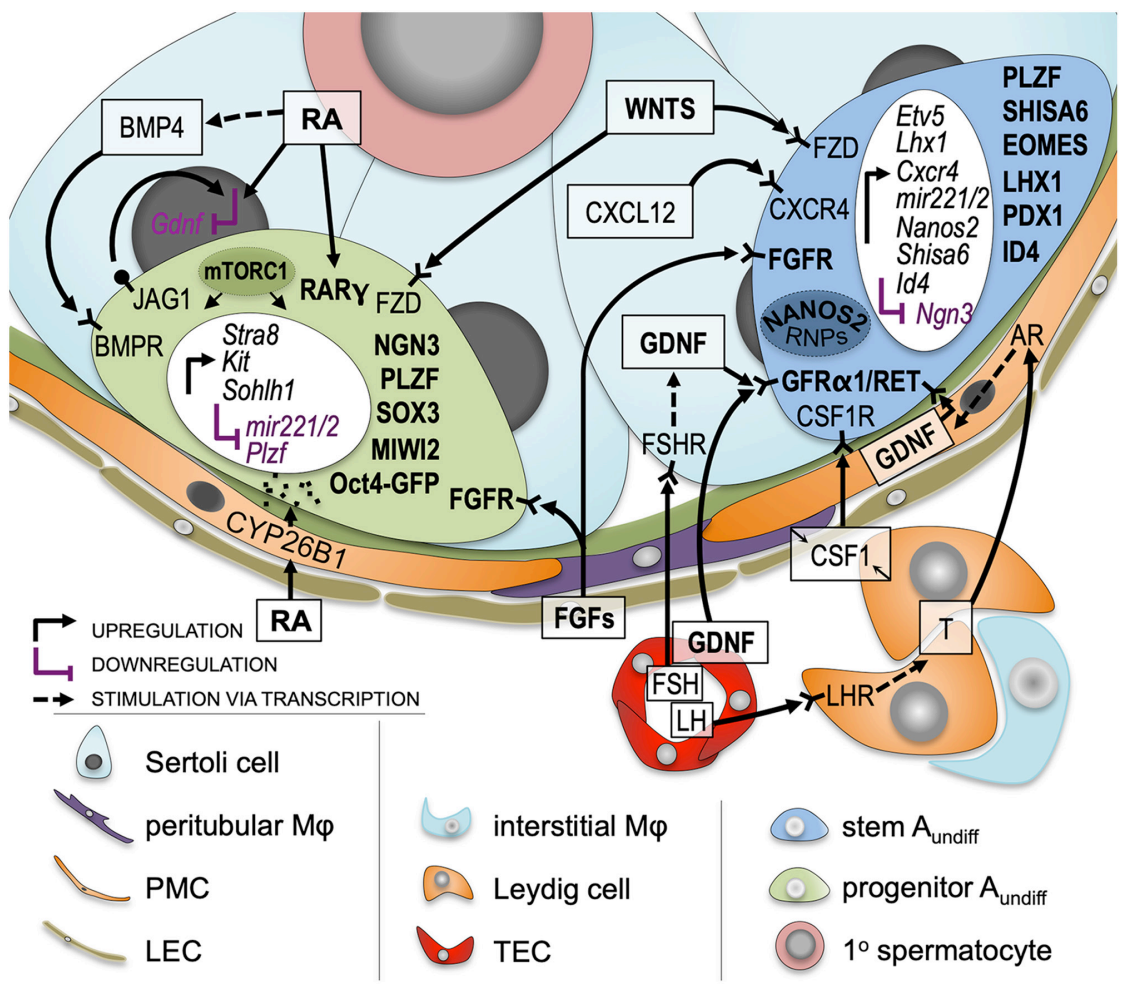

Figure 3 Regulation of $\mathrm{A}_{\text {undiff }}$ in the adult mouse. The adult mouse SSC niche is formed by contributions from different somatic cell types and germ cells. The response of $A_{\text {undiff }}$ to niche-derived cues is determined by receptors and other proteins that they express. GFR $\alpha 1$-positive stem- $\mathrm{A}_{\text {undiff }}$ (blue; PLZF/SHISA6/PDX1+) respond to GDNF and other factors by upregulating genes that are needed to maintain the self-renewing state, including Etv5, Lhx1, Cxcr4, Nanos2 and Id4. SHISA6 is a WNT inhibitor and makes these cells refractory to WNT-mediated differentiation priming. Differentiation-primed progenitor $\mathrm{A}_{\text {undiff }}$ (green; NGN3/SOX3/PLZF+) are derived from GFR 1-positive cells in response to WNT stimulation. They have adopted a gene expression signature (NGN3, SOX3) that clearly separates them from the self-renewing cells and confers on them a capability to respond to differentiation-inducing RA via expression of RAR $($ retinoic acid receptor gamma). RA stimulus evokes a differentiation commitment in these cells leading to upregulation of Stra8, Kit and Soh/h1, and downregulation of Plzf and Kit-degrading miR221/2. RA also acts on Sertoli cells and stimulates the expression of differentiation and cell survival-promoting agents, such as BMP4 (dashed arrow) while simultaneously down-regulating Gdnf. JAG1 expressed by germ cells also suppresses Gdnf expression in Sertoli cell via Notch signaling. RA is synthesized by Sertoli cells and primary spermatocytes. CYP26B1 enzyme in PMCs degrades extratubular RA. GDNF secretion is under endocrine regulation (dashed arrows) both in Sertoli cells (FSH) and PMCs via LH-stimulated testosterone (T) synthesis in Leydig cells. CSF1 is likely derived from multiple sources, at least Leydig cells and peritubular macrophages (M $\varphi$ ), potentially also from select PMCs. Testicular interstitium, with both vascular and lymphatic endothelial cells (TECs and LECs), is a rich source of factors implicated in SSC self-renewal.

like microenvironment is recreated upon genotoxic stress (Zohni et al. 2012).

\section{Niche factors}

\section{GDNF}

GDNF is produced by testicular somatic cells. While Sertoli cells have been considered the primary source of GDNF during steady-state spermatogenesis, TECs express Gdnf at a higher level than Sertoli cells and might be the major GDNF-producing population in the testis (Meng et al. 2000, Chen et al. 2016, Bhang et al. 2018). Interestingly, peritubular myoid cells secrete GDNF under androgen stimulation, and studies conducted using PMC-specific conditional Gdnf-knockout mice indicated that long-term maintenance of male fertility depended on PMC-derived GDNF (Chen et al. 2016). However, the validity of these data have subsequently been questioned since the Cre model that was used is not specific for PMCs but is also expressed by TECs (Chen et al. 2016, Chen \& Liu 2016). Future investigations are warranted to elucidate the role of distinct sources of GDNF for the maintenance of SSCs and normal cyclic function of the seminiferous epithelium.

GDNF is indispensable for maintenance of SSCs both in vivo and in vitro (Meng et al. 2000, Kubota et al. 2004). Conversely, overexpression or increased availability of GDNF results in the accumulation of $\mathrm{A}_{\text {undiff }}$ spermatogonia (Meng et al. 2000, Uchida et al. 2016, Masaki et al. 2018a, Sharma \& Braun 2018, Faisal et al. 2019). GDNF acts on $A_{\text {undiff }}$ via binding to the GFR $\alpha \mathbf{1} / \mathbf{R E T}$ receptor complex on their cell surface and subsequent activation of PI3K/AKT, RAS/ERK MAPK 
and SRC family kinase pathways (Airaksinen \& Saarma 2002, Oatley et al. 2007, Lee et al. 2007, He et al. 2008). SHP2 protein tyrosine phosphatase encoded by the Ptpn 11 (protein tyrosine phosphatase, non-receptor type 11) gene is a key regulator of GDNF signaling within SSCs (Puri et al. 2014). Deletion of GDNF receptor components triggers rapid SSC depletion resulting in a Sertoli-cell-only phenotype (Meng et al. 2000, Naughton et al. 2006). The expression of GFR 1 within the $A_{\text {undiff }}$ is reduced as the syncytial length is increased. While approx. $90 \%$ of $\mathrm{A}_{\mathrm{s}}$ spermatogonia express GFR $\alpha 1$, approx. $75 \%$ of $A_{p r} 40 \%$ of $A_{a \mid 4}$ and $15 \%$ of $A_{a \mid 8}$ are positive for GFR $\alpha 1$, whereas $A_{a l 16}$ lack GFR $\alpha 1$ expression altogether (Nakagawa et al. 2010). In addition, the expression level per cell is typically lower in aligned syncytia than single cells or pairs (Grasso et al. 2012). Interestingly, GDNF has been shown to regulate the expression of Gfra 1 in $\mathrm{A}_{\text {undiff }}$ through a long non-coding RNA which is a partial anti-sense transcript of Grra1 (Li et al. 2016).

Gdnf itself is regulated in Sertoli cells by a combination of endocrine, paracrine and autocrine mechanisms (Tadokoro et al. 2002, Simon et al. 2007, Garcia et al. 2014, 2017, Mäkelä et al. 2014). Interestingly, Notch signaling, activated by germ cell-expressed ligand JAG1 (jagged 1), has been implicated in negative regulation of Gdnf expression in Sertoli cells (Garcia et al. 2014, 2017). Gdnf expression in Sertoli cells is also downregulated by FGF2 and RA (see below), which thus function to oppose GDNF (Hasegawa et al. 2013, Masaki et al. 2018a). The role of pituitary-derived follicle-stimulating hormone $(\mathrm{FSH})$ in Gdnf regulation is often emphasized. The evidence for in vivo stimulation of Gdnf expression by FSH is, however, rather limited and contradictory (Tanaka et al. 2016, Sakai et al. 2018). Moreover, FSH is a general regulator of the Sertoli cell transcriptome (McLean et al. 2002). Thus, underlining its putative stimulatory role on Gdnf might be misleading if we do not know how FSH affects the balance of selfrenewal vs differentiation-promoting factors as a whole.

GDNF regulates gene expression in $\mathrm{A}_{\text {undiff, }}$ and its target genes, including Nanos2, Etv5, Lhx 1, T(Brachyury), Bcl6b, Id4 and Cxcr4, have been implicated in the maintenance of the self-renewing state and/or prevention of differentiation (Chen et al. 2005, Oatley et al. 2006, 2007, 2011, Sada et al. 2012, Yang et al. 2013a). Moreover, GDNF downregulates Ngn3 to promote the self-renewing state (Kaucher et al. 2012). In addition to these, a number of GDNFindependent proteins (including PLZF, FOXO1, GILZ and TAF4B) working in SSCs in a cell-autonomous fashion to promote SSC survival and self-renewal have been identified (Buaas et al. 2004, Costoya et al. 2004, Falender et al. 2005, Goertz et al. 2011, La et al. 2018a). While the role of extrinsic factors in the regulation of SSCs is often highlighted, SSC-intrinsic factors are just as relevant in the maintenance of stem cell function. Other paracrine factors involved in SSC maintenance in synergy with GDNF include CXCL12 (see below) and different isoforms of VEGFA (vascular endothelial growth factor A) (Caires et al. 2012, Yang et al. 2013a).

\section{FGFs}

FGFs (at least FGF2, 4, 5 and 8) exert a mitogenic effect on $\mathrm{A}_{\text {undiff }}$ (Kubota et al. 2004, Kitadate et al. 2019). FGF2 and GDNF work in synergy to promote the robust growth of $\mathrm{A}_{\text {undiff }}$ in vitro (Kubota et al. 2004, Kanatsu-Shinohara et al. 2005, Ishii et al. 2012, La et al. 2018b). However, the exact significance of FGF2 for maintenance of SSCs in vivo remains an area of active study. Interestingly, prolonged stimulation with FGF2 in vivo results in the accumulation of progenitor $A_{\text {undiff }}$ (Masaki et al. 2018). These data support our in vitro findings indicating a differentiation-promoting effect for FGF2 on $A_{\text {undiff }}$ (Masaki et al. 2018, La et al. 2018b). FGF2 also regulates the availability of RA by suppressing the expression of RA-degrading enzyme Cyp26b1 (Masaki et al. 2018a). Interestingly, GDNF expression in TECs is stimulated by FGF2 providing a mechanism for observed synergy between these two factors (Bhang et al. 2018). The origin of testicular FGF2 remains contentious (Mullaney \& Skinner 1992, Masaki et al. 2018, Kitadate et al. 2019). Apparently, $A_{\text {undiff }}$ can be maintained in vitro in GDNF-free conditions in the presence of FGF2 but they display poor growth and low stemness (as judged by transplantation assay) in these conditions (Takashima et al. 2015, La et al. 2018b).

Vasculature-associated LECs plus select interstitial cells secrete FGF4, 5 and $\mathbf{8}$. Both stem and progenitor $\mathrm{A}_{\text {undiff }}$ express the molecules needed to bind and internalize FGF signals, and in the presence of GDNF, FGFs were proposed to promote SSC proliferation plus self-renewal (over differentiation), and thus regulate SSC density, i.e. number of SSC niches (Kitadate et al. 2019). Notably, LECs provide a constant supply of FGFs over the course of the seminiferous epithelial cycle, which contrasts with GDNF, WNT and RA signals. It is therefore unclear how FGF action is tethered into stage-specific regulation of SSCs, such as proliferation. Kitadate et al. (2019) propose a minimal model in which SSCs compete for a limited supply of FGFs whose availability on the basement membrane is inversely proportional to the distance from the source (vasculature-proximal LECs and interstitium) and number of $A_{\text {undiff }}$ (the FGF sink) (Kitadate et al. 2019). It is unclear why the effects of distinct FGF ligands (FGF2 vs FGF4/5/8) on SSCs are so different. However, much can be explained by different study settings (in vitro vs in vivo), dosage and dependency on physiological levels of GDNF signaling.

The WNT pathway has recently been implicated in differentiation priming in the male germline 
(Takase \& Nusse 2016, Tokue et al. 2017). Tokue et al. (2017) demonstrated that transition from stem (GFR $\alpha 1+$ ) to progenitor $(\mathrm{NGN} 3+)$ state is driven by WNT/ $\beta$-catenin signaling (Tokue et al. 2017). Moreover, they identified SHISA6, a cell-autonomous WNT inhibitor, as a novel marker for a subset of GFR $\alpha 1$-expressing $A_{\text {undiff }}$ SHISA6 might thus act as a WNT trap in this subset of $A_{\text {undiff }}$ to maintain the self-renewing state and prevent premature entry into the differentiation-primed state.

Interestingly, the availability of GDNF and WNT6, a WNT family member that is abundantly expressed by Sertoli cells, during the seminiferous epithelial cycle differs, suggesting that they have distinct windows of action (Takase \& Nusse 2016, Tokue et al. 2017). Androgen-regulated Sertoli cell gene WNT5A has also been implicated in control of SSC self-renewal, but the available data indicate that WNT5A is an $A_{\text {undiff }}$ mitogen (Tanaka et al. 2016). Whether it supports adoption of either the stem or progenitor state is unclear. Moreover, Wnt5a expression is downregulated in the testis soon after birth, and in the adult mouse Wnt5a levels are relatively low suggesting that it might be a developmental regulator of the SSC niche (Tanaka et al. 2016, Faisal et al. 2019).

\section{Retinoic acid}

Retinoic acid (RA) is a potent hormone that plays an indispensable role in the induction of differentiation in the male germline. Lack of RA or vitamin A (RA is a vitamin $A$ metabolite) results in the accumulation of $A_{\text {undiff }}$ that are cleared through differentiation once normal RA metabolism is re-established in the seminiferous epithelium (Morales \& Griswold 1987, van Pelt \& de Rooij 1990). Exposure of differentiation-primed $A_{\text {undiff }}$ to $R A$ results in their commitment to spermatogenesis (transition to type $\mathrm{A} 1$ differentiating spermatogonia) and makes them refractory to niche-derived factors (Endo et al. 2015).

Notably, RA opposes GDNF function at two different levels: it downregulates the expression of Gdnf in Sertoli cells (and stimulates the expression of differentiation-supporting factors, such as Bmp4 and $S C f)$ and antagonizes the effect of GDNF in $A_{\text {undiff }}$ (Pellegrini et al. 2008, Carlomagno et al. 2010, Barrios et al. 2012, Yang et al. 2013b). RA is primarily produced by Sertoli cells within the testis but recent research suggests that meiotic and post-meiotic germ cells are intimately involved in the regulation of RA availability during the seminiferous epithelial cycle (Raverdeau et al. 2012, Sugimoto et al. 2012, Endo et al. 2017, Mäkelä \& Toppari 2018a, Teletin et al. 2019). Peritubular macrophages have also been implicated in RA-mediated control of spermatogonial differentiation but the physiological significance of these findings remains unclear (DeFalco et al. 2015).

\section{CXCL12}

CXCL12 (C-X-C motif chemokine ligand 12) and its cognate receptor CXCR4 (C-X-C motif chemokine receptor 4) play significant roles during male germline development (for a review see Loveland et al. 2017) and have also been implicated in the maintenance of SSCs (Kanatsu-Shinohara et al. 2012). CXCL12/CXCR4 signaling is crucial for proper homing of SSCs to their cognate niche at the basement membrane and might also keep SSCs from leaving the niche (Kanatsu-Shinohara et al. 2012, Yang et al. 2013a). Notably, expression of Cxcr4 is also stimulated by GDNF in $\mathrm{A}_{\text {undiff }}$ (KanatsuShinohara et al. 2012, Yang et al. 2013a). CXCL12 is potentially produced by Sertoli cells but definitive data are lacking. The data concerning the mitogenic effect of CXCL12/CXCR4 signaling on $\mathrm{A}_{\text {undiff }}$ are contradictory but it has been suggested to promote the self-renewing state and prevent transition into the progenitor state in cultured $\mathrm{A}_{\text {undiff }}$ (Kanatsu-Shinohara et al. 2012, Yang et al. 2013a).

\section{CSF1}

CSF1 (colony-stimulating factor 1) does not affect the proliferation of cultured $A_{\text {undiff }}$ but increases their stemness, that is, the ability to give rise to spermatogenic colonies after transplantation (Oatley et al. 2009). The role of CSF1 in vivo is not clear due to endocrine effects of Csf1 deficiency on fertility (op/op) (Cohen et al. 1996). Notably, $\mathrm{A}_{\text {undiff }}$ display a highly enriched expression for Csf1r, the receptor for CSF1 (Oatley et al. 2009). Oatley et al. (2009) showed the expression of CSF1 in interstitial Leydig cells and select peritubular cells (Oatley et al. 2009). Further, a recent report by DeFalco et al. (2015) suggests that these rare CSF1-positive peritubular cells might actually be peritubular macrophages (DeFalco et al. 2015). CSF1 expression was also demonstrated in interstitial macrophages and vascular smooth muscle cells (DeFalco et al. 2015). The issue, however, warrants further investigation (Fig. 3).

\section{Regulation of cell fate decisions in the SSC niche Maintenance of the self-renewing state}

GDNF is indispensable for maintenance of the GFR $\alpha 1$ expressing $A_{\text {undiff }}$ subset, that is thought to contain or possibly form (through active interconversion between equipotent singly isolated and short syncytial states, Figs 1 and 2) the steady-state stem cell population of the adult mouse testis (Meng et al. 2000, Hara et al. 2014). However, it does not achieve this alone but in collaboration with SSC-autonomous factors, including PLZF, FOXO1, GILZ and TAF4B (Buaas et al. 2004, Costoya et al. 2004, Falender et al. 2005, Goertz et al. 2011, La et al. 2018a). 
PLZF (promyelocytic leukemia zinc finger) is expressed throughout the $\mathrm{A}_{\text {undiff }}$ population plus spermatogonia at early differentiation stages and plays a key cell-autonomous role in promoting SSC selfrenewal. Accordingly, loss of functional PLZF results in progressive germ cell loss, testicular hypoplasia and infertility (Buaas et al. 2004, Costoya et al. 2004, Fischer et al. 2008). PLZF is a transcriptional regulator that can both stimulate and repress the expression of its target genes (David et al. 1998). In mouse SSCs, PLZF has been suggested to work in at least three different ways to ensure SSC maintenance: firstly, by modulating activity of SALL4, whose action is associated with spermatogonial differentiation; secondly, by directly and indirectly (via Foxo1 and Etv5, e.g.) repressing differentiation genes (including Kit) and stimulating spermatogonial stemness genes (many of which are also GDNF targets); and thirdly, by indirectly opposing the mTORC1 pathway through upregulation of Ddit4 (Filipponi et al. 2007, Hobbs et al. 2010, 2012, 2015, Lovelace et al. 2016, Chan et al. 2017). The fact that GDNF signaling and PLZF share a number of important target genes (Bcl6b, Etv5 and Lhx1) strongly supports a model in which PLZF operates in a molecular circuit that amplifies the responsiveness to GDNF as a means to maintain SSCs (Song \& Wilkinson 2014, Lovelace et al. 2016).

FOXO1 (Forkhead box protein O1) belongs to the family of forkhead transcription factors that have pleiotropic cell regulatory functions. In the mouse testis, loss of Foxo 1 results in spermatogenic failure due to defective SSC maintenance and a block in spermatogenesis (Goertz et al. 2011). FOXO1 exerts its effect on spermatogenesis through regulation of several genes specifically or highly expressed by the SSCs (including Ret, Lhx1, Egr2 and Sall4) and needed for their maintenance (Goertz et al. 2011). Whether FOXO1 directly regulates these genes in $\mathrm{A}_{\text {undiff }}$ awaits further study.

Deletion of Gilz results in rapid exhaustion of $\mathrm{A}_{\text {undiff }}$ and degeneration of the germline through aberrant activation of the mTORC1 pathway in SSCs (La et al. 2018a). In WT SSCs, GILZ negatively regulates mTORC1 activity through a number of potential mechanisms, including suppression of ERK MAPK signaling and maintenance of expression of deubiquitinase USP9X. GILZ also plays a key role in spermatogenesis and promotes the expression of factors such as ZMYM3, which are required for spermatogenesis, in an mTORC1-independent fashion (Romero et al. 2012, La et al. 2018a).

TAF4B (TATA-box binding protein associated factor 4b) is a gonad-specific subunit of transcription initiation factor TFIID. Taf $4 b$-null mice recapitulate the phenotype that is shared by many genes with a role in SSC maintenance: progressive loss of germ cells eventually leading to Sertoli-cell-only phenotype in most, if not all, seminiferous tubules (Falender et al. 2005). Taf $4 b$-deficient mice become infertile by 3 months of age, but the phenotype may not solely originate from SSC maintenance defects since perinatal germ cell development (gonocyte-to-spermatogonia transition, e.g.) is disrupted in these mice (Falender et al. 2005, Lovasco et al. 2015).

Data also demonstrate that maintenance of SSCs relies on sequestering differentiation-promoting factors, including components of the mTORC1 pathway, in ribonucleoprotein (RNP) complexes by the RNAbinding protein NANOS2, and the self-renewal promoting cellular transcriptome is thus partially indirectly achieved (Zhou et al. 2015). This likely provides SSCs with a fail-safe mechanism and buffers against undesirable effects of stochastic changes in transcriptional activity. Moreover, proteins and mRNAs trapped in RNP complexes might have an essential role in efficient and synchronous differentiation commitment once RNPs dissociate and the sequestered molecules are released into the cytoplasm. Recently, it was shown that NEDD4 (neural precursor cell expressed developmentally downregulated protein 4-1), an E3 ubiquitin ligase, targets NANOS2 for degradation, and thus promotes differentiation (Zhou et al. 2017). NANOS2 also associates with DND1 (Dead end protein homolog 1) in $A_{s}$ and $A_{p r}$ and deletion of either results in gradual depletion of SSCs (Sada et al. 2009, Niimi et al. 2019).

Of the numerous GDNF target genes, the role of ID4 in $\mathrm{A}_{\text {undiff }}$ has been most extensively studied. $\mathrm{A}_{\text {undiff }}$ display a heterogeneous expression for $I d 4$, with the highest levels in stem populations (Oatley et al. 2011, Helsel et al. 2017, (La et al. 2018b). Importantly, overexpression of ID4 blocks the stem-to-progenitor transition indicating that ID4 is a key regulator of the undifferentiated state (Helsel et al. 2017). Key regulators of $\mathrm{A}_{\text {undiff }}$ are summarized in Table 1.

In addition to these transcription factors and other proteins, a variety of epigenetic and post-transcriptional mechanisms have been implicated in the regulation of SSC maintenance and cell fate decisions within $\mathrm{A}_{\text {undiff. }}$. The latter include a number of non-coding RNAs (both short (miRNAs, e.g.) and long non-coding RNAs (IncRNAs)) with a proposed role in SSC regulation as reviewed recently elsewhere (van den Driesche et al. 2014, Hilz et al. 2016, Bie et al. 2018). Moreover, MIWI2, a protein associated with piRNA-mediated genome silencing and DNA methylation displays a restricted expression within progenitor $\mathrm{A}_{\text {undiff, }}$ the significance of which is yet to be defined (Carrieri et al. 2017, Vasiliauskaite et al. 2018). Interestingly, the epigenome (DNA methylation at CpG sites plus histone modifications) of male germ cells undergoes profound changes during fetal development, whereas in postnatal germ cells, the epigenetic marks are more stable (Mäkelä et al. 2019).

It has been shown that the epigenetic landscape of SSCs is plastic and, similar to pluripotent cell types, characterized by bivalent (both activating $\mathrm{H} 3 \mathrm{~K} 4 \mathrm{me} 3$ 
Table 1 Extrinsic and intrinsic factors with well-defined regulatory roles in maintenance or differentiation of SSCs in the adult mouse testis.

\begin{tabular}{|c|c|c|c|}
\hline Factor & Expressed in & Significance & Key references \\
\hline GDNF & SCs, TECs, PTMs & Critical for maintenance of SSCs in vivo and in vitro & $\begin{array}{l}\text { Meng et al. 2000, Kubota et al. } 2004 \\
\text { Bhang et al. } 2018\end{array}$ \\
\hline FGF4/5/8 & LECs & Regulates the number of SSCs/their niches & Kitadate et al. 2019 \\
\hline FGF2 & Likely many testis cell types & $\begin{array}{l}\text { Promotes SSC proliferation in synergy with GDNF } \\
\text { (in vitro) }\end{array}$ & $\begin{array}{l}\text { Kubota et al. 2004, Kanatsu- } \\
\text { Shinohara et al. 2005, Ishii et al. } \\
\text { 2012, La et al. 2018a }\end{array}$ \\
\hline WNT6 & SCs and interstitium & Promotes entry into the progenitor state & $\begin{array}{l}\text { Takase \& Nusse 2016, Tokue et al. } \\
2017\end{array}$ \\
\hline RA & SCs and meiotic germ cells & Induces differentiation in the germline & $\begin{array}{l}\text { van Pelt \& de Rooij 1990, Sugimoto } \\
\text { et al. 2012, Raverdeau et al. 2012, } \\
\text { Endo et al. } 2017\end{array}$ \\
\hline GFR $\alpha 1 / R E T$ & $\begin{array}{l}\text { On the cell surface of self-renewing } \\
\mathrm{A}_{\text {undiff }}\end{array}$ & $\begin{array}{l}\text { GDNF receptor complex, deletion results in rapid } \\
\text { SSC depletion }\end{array}$ & $\begin{array}{l}\text { Meng et al. 2000, Naughton et al. } \\
2006\end{array}$ \\
\hline SHISA6 & A subset of GFR $\alpha 1+A_{\text {undiff }}$ & $\begin{array}{l}\text { Confers resistance to differentiation-promoting } \\
\text { WNT/ } \beta \text {-catenin signaling }\end{array}$ & Tokue et al. 2017 \\
\hline $\mathrm{RAR} \gamma$ & Differentiation-primed $\mathrm{A}_{\text {undiff }}$ & $\begin{array}{l}\text { Required for } A_{\text {undiff }} \text { to } A_{1} \text { transition, i.e. } \\
\text { differentiation }\end{array}$ & $\begin{array}{l}\text { Gely-Pernot et al. 2012, Ikami et al. } \\
2015\end{array}$ \\
\hline PLZF & $\begin{array}{l}A_{\text {undiff }} \text { plus early differentiating } \\
\text { spermatogonia }\end{array}$ & $\begin{array}{l}\text { Promotes SSC self-renewal cell-autonomously by } \\
\text { several mechanisms }\end{array}$ & $\begin{array}{l}\text { Costoya et al. 2004, Filipponi et al. } \\
\text { 2007, Hobbs et al. 2010, } 2012\end{array}$ \\
\hline NANOS2 & $\mathrm{GFR} \alpha 1+\mathrm{A}_{\mathrm{s}}$ and $\mathrm{A}_{\mathrm{pr}}$ & $\begin{array}{l}\text { Maintains the self-renewing state by sequestering } \\
\text { differentiation-associated mRNAs in RNP } \\
\text { complexes }\end{array}$ & $\begin{array}{l}\text { Sada et al. 2009, 2012, Zhou et al. } \\
2015\end{array}$ \\
\hline ID4 & $\begin{array}{l}\text { GFR } \alpha 1+\mathrm{A}_{\text {undiff' }} \text { differentiating male } \\
\text { germ cells }\end{array}$ & Promotes the self-renewing state & Helsel et al. 2017 \\
\hline SALL4 & $\begin{array}{l}\mathrm{A}_{\text {undiff }} \text { and differentiating spermato- } \\
\text { gonia }\end{array}$ & $\begin{array}{l}\text { Required for spermatogenic differentiation and } \\
\text { long-term maintenance of SSCs }\end{array}$ & Hobbs et al. 2012, Chan et al. 2017 \\
\hline
\end{tabular}

$\mathrm{A}_{1}$, type $\mathrm{A}_{1}$ differentiating spermatogonia; $\mathrm{A}_{\text {undiff, }}$ undifferentiated type $\mathrm{A}$ spermatogonia; LECs, lymphatic endothelial cells; PTMs, peritubular myoid cells; SC, Sertoli cells; TECs, testicular endothelial cells.

and repressing $\mathrm{H} 3 \mathrm{~K} 27 \mathrm{me} 3)$ histone modifications placing promoters in a poised state capable of dynamic activation (Liu et al. 2016). Despite this potential, resolving bivalency is rarely accompanied with gene activation during early developmental transitions within the male germline leaving the significance of histone modifications for early cell fate decisions an open question (Hammoud etal. 2014). Although the global CpG methylation levels remain relatively stable in postnatal germ cells, locus-specific differential methylation in and around genes important for maintenance of a specific state, or transition into the following one, might still play an essential role in cell fate decisions within $\mathrm{A}_{\text {undiff }}$ (Kubo et al. 2015). Despite substantial research into epigenetic regulation of SSCs - summarized in Box 2 - the question as to whether dynamic changes in the epigenome regulate cell fate decisions within the $A_{\text {undiff }}$ population warrants further investigation.

\section{Differentiation priming}

To become sensitive to the differentiation-inducing stimulus (RA), $A_{\text {undiff }}$ need to exit the self-renewing state and undergo differentiation priming (Ikami et al. 2015, Tokue et al. 2017). This transition involves the activation of the mTORC1 pathway that plays a critical role in maintenance of SSCs, and aberrant mTORC1 activation promotes stem cell exhaustion (Hobbs et al. 2010, 2015, Zhou et al. 2017, La et al. 2018a). Exit from the GFR 1 1positive state entails cell size growth and induction of a transcriptional program typical of differentiation-primed undifferentiated spermatogonia or progenitors (Hobbs et al. 2010, 2015, Ikami et al. 2015). These genes, whose expression is strongly upregulated or induced, include Ngn3, Sox3, Lin28a and Rarg, whereas Gfra 1, Ret, Lhx1, Eomes and $P d x 1$ are downregulated (La et al. 2018b). WNT/ $\beta$-catenin signaling plays an important role in the differentiation priming of $A_{\text {undiff }}$ by promoting the transition from self-renewing to RA-responsive state (Yeh et al. 2012, Takase \& Nusse 2016, Chassot et al. 2017, Tokue et al. 2017). Interestingly, Tokue et al. (2017) identified SHISA6 as a novel marker for a specific subset of GFR $\alpha 1$-expressing $A_{\text {undiff }}$ (Tokue et al. 2017). SHISA6 is suggested to act as WNT signaling inhibitor and thus confer resistance to the differentiation-priming program.

\section{Differentiation commitment}

It is widely considered that induction of $\mathbf{R A R} \gamma$ in a subset of $A_{\text {undiff }}$ gives the cells a capacity to respond to RA, although alternative explanations have also recently been proposed (Gely-Pernot et al. 2012, Ikami et al. 2015, Lord et al. 2018) (Fig. 3). RA is the inducer of differentiation in the germline and to prevent premature exit from the progenitor state (that displays latent self-renewal capacity), its local availability and RAR $\gamma$ expression need to be tightly regulated within the seminiferous epithelium (Mäkelä \& Toppari 2018a). Extratubular RA that might interfere with proper timing of spermatogenic onset (from circulation or testicular 


\section{Box 2: Epigenetic regulation of $A_{\text {undiff }}$}

KDM1A (lysine (K)-specific demethylase 1A) is a histone $\mathrm{H} 3$ lysine demethylase with gene-regulating activities including but not limited to removal of mono- and di-methylation at lysine 4 on histone $\mathrm{H} 3(\mathrm{H} 3 \mathrm{~K} 4)$. KDM1A is needed for postnatal maintenance of the germline, and its loss results in rapid depletion of all germ cells potentially due to destabilization of gene expression and the consequent inability to maintain functional SSCs or the spermatogenic process (Lambrot et al. 2015, Myrick et al. 2017). However, available data do not allow definitive conclusions to be drawn and further studies are needed to elucidate the functional role of KDM1 A in $\mathrm{A}_{\text {undiff: }}$.

KMT2B is a H3K4 methyltransferase whose action in $A_{\text {undiff }}$ has been proposed to epigenetically prime two sets of promoters, one activated during late spermatogenesis and the other after fertilization (Tomizawa et al. 2018). Kmt $2 b$ deletion in the adult testis results in an early block in differentiation. However, poor growth of $K m t 2 b$-deleted SSCs in vitro suggests that KMT2B is important for SSC maintenance/expansion (Tomizawa et al. 2018). H3K4me2/3 established by KMT2B and related proteins, function as docking sites for transcriptional co-regulators, such as PHF13 (PHD finger protein 13), an epigenetic modifier also associated with long-term maintenance of SSCs (Bordlein et al. 2011, Chung et al. 2016).

PRC1 (Polycomb repressive complex 1) has been suggested to coordinate timely activation of gene expression during spermatogenesis (Maezawa et al. 2017). PRC1 component RNF2 (Ring finger protein 2) is an E3 ubiquitin ligase for histone H2A, and induces expression of plus forms complexes with SALL4, a transcription factor required for both spermatogenic differentiation and long-term maintenance of SSCs (Hobbs et al. 2012, Chan et al. 2017, Maezawa et al. 2017). Germ cell-specific ablation of RNF2 results in the deregulation of spermatogonial gene expression and a consequent early block in spermatogenesis (Maezawa et al. 2017). The list of dysregulated genes includes factors with previously characterized roles in SSC maintenance, like Plzf and $\boldsymbol{R} \boldsymbol{b}$ (retinoblastoma protein) (Buaas et al. 2004, Costoya et al. 2004, Hu et al. 2013, Maezawa et al. 2017). At least some of the genomic effects of RNF2 seem to be unrelated to its histone H2A E3 ubiquitin ligase activity and association with PRC1.

An additional factor associated with PRC1, SCML2 ( $\mathrm{Scm}$ Polycomb Group Protein Like 2), is a germline-specific Polycomb protein, and a potential epigenetic regulator of distinct $\mathrm{A}_{\text {undiff }}$ states due to its active role in establishing gene-silencing epigenetic marks $\mathrm{H} 3 \mathrm{~K} 27 \mathrm{me} 3$ and H2AK119ub in the male germline (Hasegawa et al. 2015, Maezawa et al. 2018). SCML2 is recruited to epigenetically active loci in $A_{\text {undiff }}$ and mediates gene silencing by forming a complex with PRC2. SCML2 thus complexes with both PRC1 and PRC2 to repress and coordinate timely expression of genes in the male germline. A similar process might regulate gene expression in distinct subsets of $\mathrm{A}_{\text {undiff. }}$ Despite relatively high expression of SCML2 in $\mathrm{A}_{\text {undiff, }}$ the effects of its depletion on these cells are rather modest.

An invaluable insight into the significance of epigenetic regulators for $\mathrm{A}_{\text {undiff }}$ is provided by $\boldsymbol{K} \boldsymbol{d} \boldsymbol{m} \boldsymbol{6} \boldsymbol{b}$-deficient (lysine demethylase $6 \mathrm{~B}$ ) mice (Iwamori et al. 2013). KDM6B removes methyl groups from H3K27 and hence promotes gene activation. Loss of Kdm6b destabilizes intercellular bridges (ICBs) (Mäkelä \& Toppari 2018b) in $\mathrm{A}_{\text {undiff }}$ and results in higher incidence of $\mathrm{A}_{\mathrm{s}}$ spermatogonia (Iwamori et al. 2013). As a likely consequence of enrichment of the self-renewing population, $K d m 6 b$-deficient mice show larger testis size and improved lifetime fertility compared to controls. These data suggest that KDM6B activity is involved in exit from the self-renewing state characterized by instability of ICBs (Mäkelä \& Toppari 2018b).

SETDB1 (SET domain, bifurcated 1) is a histone methyltransferase that represses gene expression through establishment of H3K9me3. Setdb1 knockdown in cultured SSCs results in the upregulation of genes associated with apoptotic cell death plus differentiation and impinges on their regenerative capacity (An et al. 2014). SETDB1 has recently been implicated in promoting SSC survival via PTEN/AKT/FOXO1 signaling, a previously characterized pathway involved in SSC maintenance (Goertz et al. 2011) and suppression of pro-apoptotic gene expression (Liu et al. 2017). Besides establishing H3K9me3 to silence target loci, SETDB1 may also associate with DNA methyltransferases in $\mathrm{A}_{\text {undiff }}$ to increase DNA methylation (An et al. 2014).

Methylated DNA is considered a sign of transcriptionally repressed chromatin, and activation of gene expression is typically preceded by demethylation in and around the transcribed locus. Interestingly, differentiation commitment in the male germ line is accompanied by substantial upregulation of de novo DNA methyltransferases DNMT3A and DNMT3B, and destabilization of the DNA methylation machinery interferes with spermatogenic differentiation (Shirakawa et al. 2013). Further, entry of peripubertal undifferentiated spermatogonia to a differentiating state involves considerable demethylation in specific regions within the genome (Kubo et al. 2015). These regions harbor key genes associated with and indispensable for spermatogonial self-renewal and differentiation (Kubo et al. 2015). Moreover, male mice lacking Dnmt3l, which lacks enzymatic activity but acts as a processive catalyst and cooperates with DNMTs, lose all their germ cells by early adulthood (Hata et al. 2002, 2006). DNMT3L is proposed to control $\mathrm{A}_{\text {undiff }}$ proliferation and differentiation commitment, although other groups have reported that DNMT3L is essentially absent from spermatogonia, casting doubt on a direct role in $\mathrm{A}_{\text {undiff }}$ regulation (Sada et al. 2009, van Pelt \& de Rooij 1990).

interstitium, including macrophages) is thought to be degraded by the CYP26B1 enzyme expressed in the PMCs (Vernet et al. 2006, MacLean et al. 2007, DeFalco et al. 2015). As reviewed by us elsewhere, an ingenious system that probably involves the action of all the different cell types of the seminiferous tubule (PMC, Sertoli cells, 4-5 generations of germ cells) ensures that RA-induced differentiation of spermatogonia takes place specifically at stages VIIVIII of the mouse seminiferous epithelial cycle (Mäkelä \& Toppari 2018a).
Sertoli cell-derived RA is considered to induce the developmental onset of spermatogenesis in an asynchronous manner over the length of the seminiferous tubule resulting in the formation of the spermatogenic wave (Raverdeau et al. 2012, Tong et al. 2013). Meiotic germ cells have also been shown to take part in RA metabolism within the seminiferous epithelium, and the seminiferous cycle has been proposed to be maintained by RA produced by preleptotene and late pachytene spermatocytes (Vernet et al. 2006, Raverdeau et al. 2012, Davis et al. 2013). This system would ensure that a 
new cohort of germ cells is recruited into spermatogenic differentiation after every 8.6-day interval (the duration of the seminiferous cycle in mouse) at stages VII-VIII of the seminiferous epithelial cycle (Mäkelä \& Toppari 2018a). However, in the light of recent studies, it is difficult to draw conclusions about the significance of RA from different sources (Sertoli and germ cells) for the onset and completion of distinct RA-dependent events during spermatogenesis, and it is possible that these two intratubular sources of RA are functionally redundant (Endo et al. 2017, Teletin et al. 2019). Sequestration and storage of RA precursors by round spermatids at stages II-VI has been proposed as a mechanism to prevent the premature entry of differentiation-primed RAR $\gamma$ expressing $\mathrm{A}_{\text {undiff }}$ into spermatogenesis (Sugimoto et al. 2012). Then, specifically at stages VII-VIII as a result of RA action, the RAR $\gamma$-positive subset of $A_{\text {undiff }}$ transits into type A1 differentiating spermatogonia and starts to express early markers of spermatogenic differentiation, including KIT and STRA8 (Schrans-Stassen et al. 1999, Pellegrini et al. 2008, Zhou et al. 2008, Ikami et al. 2015).

\section{Stage dependency of the SSC niche}

This seemingly complex interplay of GDNF, WNT and RA signaling becomes more understandable when we consider the temporal aspect (Fig. 4A). Mouse spermatogenesis can be divided into stages (I-XII) (Leblond \& Clermont 1952). The stages form segments and follow each other in a logical order along the length of seminiferous tubule to establish the wave of the seminiferous epithelium. Gdnf mRNA and reporter activity is found at the highest level in stages XII-IV, whereas Wnt6 is most highly expressed at stages I-VIII (Grasso et al. 2012, Tokue et al. 2017). The level of RA is strictly regulated and the seminiferous epithelium is exposed to an RA pulse commencing at late stage VII (Hogarth et al. 2015, Endo et al. 2017). The highest levels of RA are recorded at stage VIII-IX, but RA is present at a relatively high concentration throughout stages $\mathrm{VII-XII}$ (Fig. 4A). GDNF/WNT6 and RA levels thus mirror each other suggesting that RA availability might regulate the expression of both Gdnf and Wnt6 during the course of mouse seminiferous epithelial cycle. Moreover, the availability of mitogenic, self-renewal-promoting FGFs is possibly highest at late stages due to their inverse dependence on the number of proposed FGF sinks, i.e. $A_{\text {undiff }}$ (Kitadate et al. 2019).

Based on available data, a following model for the regulation of SSC niche in mouse is proposed: GDNF plus FGFs synergistically induce self-renewal of SSCs at stages X-II (Tegelenbosch \& de Rooij 1993, Sharma \& Braun 2018). WNT6 then acts on the SHISA6-negative subset of $A_{\text {undiff }}$ to prime the cells for differentiation. As a part of that program, RAR $\gamma$ is induced and the progenitors become sensitive to RA between stages II and VI (Endo et al. 2015, Ikami et al. 2015). A pulse of RA at stages
VII-IX results in the differentiation commitment of these cells. Reducing levels of RA and a sharp decline in the number of FGF-consuming cells (due to $\mathrm{A}_{\text {undiff }}$-to-A1 transition) at late stages allow GDNF and FGF levels, respectively, to rise resulting in the next wave of $A_{\text {undiff }}$ proliferation at stages X-II and so on (Fig. 4B).

\section{Functional dissection of adult SSC niche}

We have recently defined the molecular signatures of self-renewing and differentiation-primed $\mathrm{A}_{\text {undiff }}$ subsets (La et al. 2018b). Generation of a compound reporter mouse line based on distinct expression of fluorescent proteins under Plzf and Oct4 promoters enabled us to functionally dissect the $A_{\text {undiff }}$ pool and shed light on the heterogeneity within the GFR $\alpha 1$-positive population.
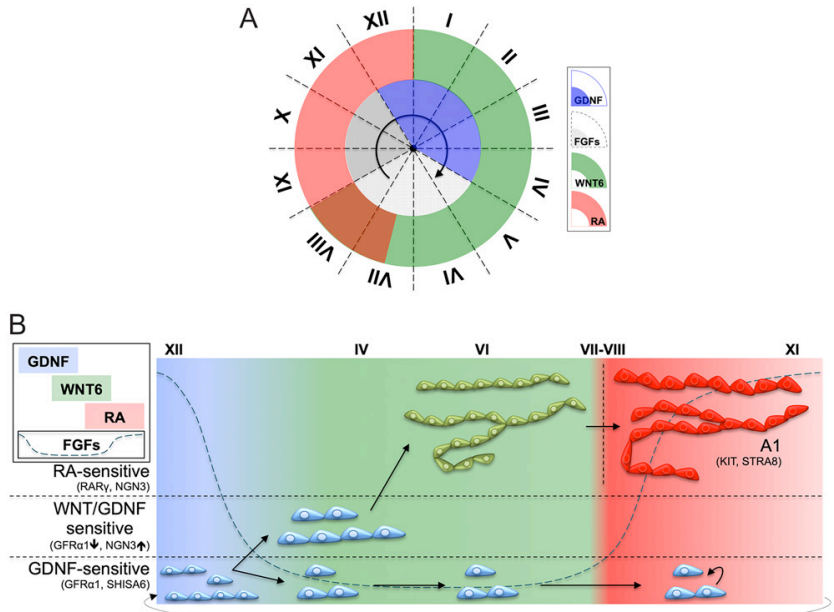

Figure 4 Regulation of the mouse SSC niche. (A) SSC niche clock. The availability of all three key factors (GDNF, WNT6 and RA) is tightly regulated during the cycle of the seminiferous epithelium. The highest level of GDNF and WNT6 is supposedly present at stages XII-IV and I-VIII, respectively, whereas a peak of RA has been measured at stages VIII-IX, but RA levels stay at a relatively high level throughout stages VII-XII. WNT6 and RA act on a common $\mathrm{A}_{\text {undiff }}$ subset, whereas GDNF is considered to exert its effect specifically on the self-renewing $A_{\text {undiff }}$ subset (that is insensitive to WNT6/RA) under homeostatic conditions. Based on cyclical oscillations in the size of the proposed FGF sink ( $\left.A_{\text {undiff }}\right)$, we hypothesize that the availability of LEC-derived FGFs is highest in stages IX-II. (B) Expansion of $A_{\text {undiff }}$ and cell fate decisions within the SSC niche during the course of the seminiferous epithelial cycle. GDNF-sensitive $\mathrm{A}_{\text {undiff }}$ are exposed to increasing levels of GDNF and FGFs and respond to it by undergoing mitosis in stages X-II. A subset of the progeny becomes sensitive to differentiation-priming WNT6, that is upregulated at stage I on. This developmental program prepares the cells for differentiation and encompasses a shift in their transcriptome characterized by upregulation of Rarg and Ngn3, and downregulation of Gfra 1. Differentiation-primed $\mathrm{A}_{\text {undiff }}$ thus become insensitive to physiological steady-state levels of GDNF and acquire competence to respond to differentiation-inducing RA by stage VII-VIII when they irreversibly transit to type A1 differentiating spermatogonia. RA-insensitive $A_{\text {undiff }}$ are unaffected by the RA pulse and they are ready respond to the following wave of high GDNF/FGFs. 
We further identified an unappreciated, adult testisspecific subset of GFR 1 1-positive spermatogonia that displays a unique co-expression of $P d x 1$, Brachyury, Eomes and $L h \times 1$. This $\mathrm{A}_{\text {undiff }}$ subset constitutes less than $0.2 \%$ of testicular cells in the adult mouse ( $\mathrm{La}$ et al. 2018b).

Our data suggest that GFR $\alpha 1+$ spermatogonia adopt different self-renewing states based on availability of niche factors. The self-renewing state marked by PDX1, EOMES and LHX1 prevails under tissue homeostasis. During development and under regenerative conditions, that is when temporary expansion of the SSC population is required, Eomes and $L h \times 1$ are upregulated, whereas $P d x 1$ is downregulated, likely due to niche-derived cues (La et al. 2018b). These data suggest that the state marked by PDX1, EOMES and LHX1 might be optimized for long-term maintenance of SSCs under steady-state spermatogenesis.

The PDX1-positive $A_{\text {undiff }}$ subset displays enriched stem cell activity in transplantation studies, although transplantation activity was not limited to this population. In vitro culture of $\mathrm{A}_{\text {undiff }}$ demonstrated that the number of PDX1-positive $A_{\text {undiff }}$ declines upon passaging, at high cell density and in conditions where GDNF availability becomes limiting. Surprisingly, we also found that Oct4-GFP, classically considered to mark the stem populations, is primarily expressed in progenitors in the adult alongside Ngn3, RAR $\gamma$ and SOX3, that is in cells that are destined to differentiate under homeostatic conditions. Interestingly, Oct4-GFP becomes differentially expressed in the male germline soon after birth and delineates $A_{\text {undiff }}$ into stem and differentiation-primed subsets (Liao et al. 2019, La et al. 2018b). The extent to which the Oct4-GFP transgene faithfully marks endogenous Oct4/Pou5f1 expression in adults remains unclear. PDX1 displays a mutually exclusive expression with Oct4-GFP both in vivo and in vitro. Importantly, late passage and dense $\mathrm{A}_{\text {undiff }}$ cultures are dominated by Oct4-GFP-expressing cells, that is progenitor $\mathrm{A}_{\text {undiff, }}$ and are nearly devoid of PDX1positive cells (La et al. 2018b).

We also show that the proportion of these $A_{\text {undiff }}$ subsets can be manipulated by regulating the availability of GDNF in the culture medium: when GDNF is readily available, cultured $\mathrm{A}_{\text {undiff }}$ tend to exist in a PDX1+/Oct4GFP- (stem) state, whereas low availability of GDNF favors the PDX1-/Oct4-GFP+ (progenitor) state (La et al. 2018b). We propose that a similar mechanism controls $\mathrm{A}_{\text {undiff }}$ in vivo under steady state in a homeostatic tissue. However, in regenerative conditions or during development, when self-renewal stimuli are excessively expressed, (re)population of the seminiferous epithelium is mediated by $A_{\text {undiff }}$ of a distinct self-renewing state characterized by high expression of Eomes and Lhx 1 . PDX1 expression in $A_{\text {undiff }}$ is primarily established under homeostatic conditions. These data demonstrate that the niche status, i.e. niche-derived signals, differentially support self-renewing states. Due to the dynamic nature of the niche, different states predominate during postnatal testis development, homeostasis and regeneration after tissue damage (Fig. 5).

\section{Concluding remarks}

Our understanding concerning the regulation of the SSC niche in mice has improved considerably during the past 10 years. While Sertoli cells can still be regarded as the most important somatic cell type of the SSC niche, it is increasingly appreciated that Leydig cells, PMCs, LECs and TECs also act as key niche components. The contribution of other cell types to the niche, such as peritubular macrophages and germ cells, has been insufficiently addressed and warrants further investigation. Despite substantial progress made in the field of SSC biology, the seminal findings by Meng et al. (2000) still remain the cornerstone, and much of SSC behavior can be explained solely based on the availability of GDNF (Meng et al. 2000).

As highlighted by Potter and DeFalco (2017), the complex and compartmentalized architecture of the testicular tissue, and the intricate molecular and contact-dependent interactions between the different cell populations complicates research in general, and in particular on regulation of the SSC niche. This is also due to the fact that most factors implicated in the control

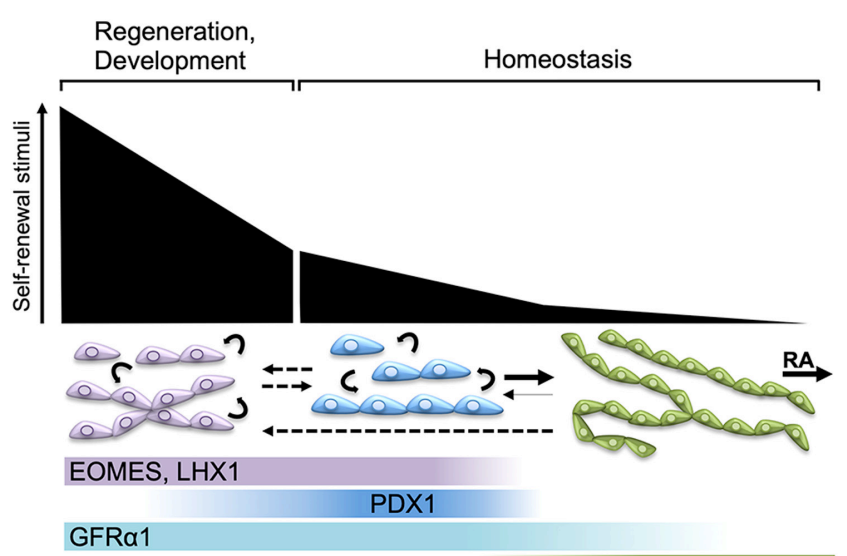

Figure 5 A simplified model describing the functional interconvertible states of $A_{\text {undiff }}$ in the mouse SSC niche. GFR $\alpha 1$-positive $A_{\text {undiff }}$ adopt distinct self-renewing states based on the availability of self-renewalpromoting stimuli expressed by the niche. When exposed to high levels of these factors, as during regeneration or development, the state marked EOMES and LHX1 (purple cells) predominates. In a homeostatic tissue, $\mathrm{A}_{\text {undiff }}$ exist in a distinct PDX1/EOMES/LHX1positive state (blue cells), potentially optimized for maintenance of life-long SSC function. If short-term expansion of $\mathrm{A}_{\text {undiff }}$ is required (regeneration), $P d x 1$ is downregulated, whereas Eomes and $L h x 1$ are upregulated. Importantly, Oct4-GFP+ $\mathrm{A}_{\text {undiff, }}$ that are destined to differentiation under steady-state can revert back to the GFR $1+$ self-renewing state if exposed to sufficiently high levels of selfrenewal stimuli, thus displaying latent stem cell capacity. 
of SSC maintenance are likely derived from multiple sources within the testis, thus probably providing a buffer mechanism against adverse environmental effects on a particular cell population. Hence, cell type-specific ablation of a given factor, for example Gdnf or Csf1, fails to provide a comprehensive answer to the question concerning its role in SSC maintenance because SSC niche-associated factors are secreted by more than one cell type within the testis.

Thanks to robust growth of $\mathrm{A}_{\text {undiff }}$ in vitro, the effect of a candidate factor is rather easy to study in culture. Novel genetic tools that enable monitoring of the composition of the $A_{\text {undiff }}$ culture (ratio: stem/progenitor) allow us to judge whether a molecule promotes the self-renewing state or if it merely acts to expand the population of differentiation-primed progenitors (La et al. 2018b). While novel molecules have been and continue to be linked with the regulation of the SSC niche, it has also been shown that the characteristics and functionality of the niche itself changes over the course of postnatal testis development and during tissue regeneration. One of the goals of future research will be to further dissect the molecular mechanisms controlling proliferation, quiescence and stem-to-progenitor transition within mouse SSCs.

\section{Declaration of interest}

The authors declare that there is no conflict of interest that could be perceived as prejudicing the impartiality of this review.

\section{Funding}

This work was supported by Emil Aaltonen Foundation (J-A M) and Australian Research Council (ARC) Future Fellowship to R M H (FT140101029).

\section{References}

Abid SN, Richardson TE, Powell HM, Jaichander P, Chaudhary J, Chapman KM \& Hamra FK 2014 A-single spermatogonia heterogeneity and cell cycles synchronize with rat seminiferous epithelium stages VIII-IX. Biology of Reproduction 90 32. (https://doi.org/10.1095/ biolreprod.113.113555)

Airaksinen MS \& Saarma M 2002 The GDNF family: signalling, biological functions and therapeutic value. Nature Reviews: Neuroscience 3 383394. (https://doi.org/10.1038/nrn812)

Aloisio GM, Nakada Y, Saatcioglu HD, Pena CG, Baker MD, Tarnawa ED, Mukherjee J, Manjunath H, Bugde A, Sengupta AL et al. 2014 PAX7 expression defines germline stem cells in the adult testis. Journal of Clinical Investigation 124 3929-3944. (https://doi.org/10.1172/JCI75943)

An J, Zhang X, Qin J, Wan Y, Hu Y, Liu T, Li J, Dong W, Du E, Pan C et al. 2014 The histone methyltransferase ESET is required for the survival of spermatogonial stem/progenitor cells in mice. Cell Death and Disease 5 e1196. (https://doi.org/10.1038/cddis.2014.171)

Barrios F, Filipponi D, Campolo F, Gori M, Bramucci F, Pellegrini M, Ottolenghi S, Rossi P, Jannini EA \& Dolci S 2012 SOHLH1 and SOHLH2 control Kit expression during postnatal male germ cell development. Journal of Cell Science 125 1455-1464. (https://doi.org/10.1242/ jcs.092593)
Bhang DH, Kim BJ, Kim BG, Schadler K, Baek KH, Kim YH, Hsiao W, Ding BS, Rafii S, Weiss MJ et al. 2018 Testicular endothelial cells are a critical population in the germline stem cell niche. Nature Communications 9 4379. (https://doi.org/10.1038/s41467-018-06881-z)

Bie B, Wang Y, Li L, Fang H, Liu L \& Sun J 2018 Noncoding RNAs: potential players in the self-renewal of mammalian spermatogonial stem cells. Molecular Reproduction and Development 85 720-728. (https://doi. org/10.1002/mrd.23041)

Bordlein A, Scherthan H, Nelkenbrecher C, Molter T, BosI MR, Dippold C, Birke K, Kinkley S, Staege H, Will H et al. 2011 SPOC1 (PHF13) is required for spermatogonial stem cell differentiation and sustained spermatogenesis. Journal of Cell Science 124 3137-3148. (https://doi. org/10.1242/jcs.085936)

Brinster RL \& Zimmermann JW 1994 Spermatogenesis following male germ-cell transplantation. PNAS 91 11298-11302. (https://doi. org/10.1073/pnas.91.24.11298)

Buaas FW, Kirsh AL, Sharma M, McLean DJ, Morris JL, Griswold MD, de Rooij DG \& Braun RE 2004 Plzf is required in adult male germ cells for stem cell self-renewal. Nature Genetics 36 647-652. (https://doi. org/10.1038/ng1366)

Caires KC, de Avila JM, Cupp AS \& McLean DJ 2012 VEGFA family isoforms regulate spermatogonial stem cell homeostasis in vivo. Endocrinology 153 887-900. (https://doi.org/10.1210/en.2011-1323)

Carlomagno G, van Bragt MP, Korver CM, Repping S, de Rooij DG \& van Pelt AM 2010 BMP4-induced differentiation of a rat spermatogonial stem cell line causes changes in its cell adhesion properties. Biology of Reproduction 83 742-749. (https://doi.org/10.1095/ biolreprod.110.085456)

Carrieri C, Comazzetto S, Grover A, Morgan M, Buness A, Nerlov C \& O'Carroll D 2017 A transit-amplifying population underpins the efficient regenerative capacity of the testis. Journal of Experimental Medicine 214 1631-1641. (https://doi.org/10.1084/jem.20161371)

Chan F, Oatley MJ, Kaucher AV, Yang QE, Bieberich CJ, Shashikant CS \& Oatley JM 2014 Functional and molecular features of the Id4+ germline stem cell population in mouse testes. Genes and Development 281351 1362. (https://doi.org/10.1101/gad.240465.114)

Chan AL, La HM, Legrand JMD, Makela JA, Eichenlaub M, De Seram M, Ramialison M \& Hobbs RM 2017 Germline stem cell activity is sustained by SALL4-dependent silencing of distinct tumor suppressor genes. Stem Cell Reports 9 956-971. (https://doi.org/10.1016/j.stemcr.2017.08.001)

Chassot AA, Le Rolle M, Jourden M, Taketo MM, Ghyselinck NB \& Chaboissier MC 2017 Constitutive WNT/CTNNB1 activation triggers spermatogonial stem cell proliferation and germ cell depletion. Developmental Biology 426 17-27. (https://doi.org/10.1016/j. ydbio.2017.04.010)

Chen SR \& Liu YX 2016 Myh11-Cre is not limited to peritubular myoid cells and interaction between Sertoli and peritubular myoid cells needs investigation. PNAS 113 E2352. (https://doi.org/10.1073/ pnas.1602873113)

Chen C, Ouyang W, Grigura V, Zhou Q, Carnes K, Lim H, Zhao GQ, Arber S, Kurpios N, Murphy TL et al. 2005 ERM is required for transcriptional control of the spermatogonial stem cell niche. Nature 436 1030-1034. (https://doi.org/10.1038/nature03894)

Chen LY, Brown PR, Willis WB \& Eddy EM 2014 Peritubular myoid cells participate in male mouse spermatogonial stem cell maintenance. Endocrinology 155 4964-4974. (https://doi.org/10.1210/en.2014-1406)

Chen LY, Willis WD \& Eddy EM 2016 Targeting the Gdnf Gene in peritubular myoid cells disrupts undifferentiated spermatogonial cell development. PNAS 113 1829-1834. (https://doi.org/10.1073/pnas.1517994113)

Chiarini-Garcia H, Hornick JR, Griswold MD \& Russell LD 2001 Distribution of type A spermatogonia in the mouse is not random. Biology of Reproduction 65 1179-1185. (https://doi.org/10.1095/ biolreprod65.4.1179)

Chiarini-Garcia H, Raymer AM \& Russell LD 2003 Non-random distribution of spermatogonia in rats: evidence of niches in the seminiferous tubules. Reproduction 126 669-680. (https://doi.org/10.1530/rep.0.1260669)

Chung HR, Xu C, Fuchs A, Mund A, Lange M, Staege H, Schubert T, Bian C, Dunkel I, Eberharter A et al. 2016 PHF13 is a molecular reader and transcriptional co-regulator of $\mathrm{H} 3 \mathrm{~K} 4 \mathrm{me} 2 / 3$. eLife $\mathbf{5} \mathrm{e} 10607$. (https:// doi.org/10.7554/eLife.10607)

Cohen PE, Chisholm O, Arceci RJ, Stanley ER \& Pollard JW 1996 Absence of colony-stimulating factor-1 in osteopetrotic (csfmop/csfmop) mice 
results in male fertility defects. Biology of Reproduction 55 310-317. (https://doi.org/10.1095/biolreprod55.2.310)

Costoya JA, Hobbs RM, Barna M, Cattoretti G, Manova K, Sukhwani M, Orwig KE, Wolgemuth DJ \& Pandolfi PP 2004 Essential role of Plzf in maintenance of spermatogonial stem cells. Nature Genetics 36 653659. (https://doi.org/10.1038/ng1367)

David G, Alland L, Hong SH, Wong CW, DePinho RA \& Dejean A 1998 Histone deacetylase associated with $\mathrm{mSin} 3 \mathrm{~A}$ mediates repression by the acute promyelocytic leukemia-associated PLZF protein. Oncogene 16 2549-2556. (https://doi.org/10.1038/sj.onc.1202043)

Davis JC, Snyder EM, Hogarth CA, Small C \& Griswold MD 2013 Induction of spermatogenic synchrony by retinoic acid in neonatal mice. Spermatogenesis 3 e23180. (https://doi.org/10.4161/spmg.23180)

de Rooij DG 2017 The nature and dynamics of spermatogonial stem cells. Development 144 3022-3030. (https://doi.org/10.1242/dev.146571)

DeFalco T, Potter SJ, Williams AV, Waller B, Kan MJ \& Capel B 2015 Macrophages contribute to the spermatogonial niche in the adult testis. Cell Reports 12 1107-1119. (https://doi.org/10.1016/j.celrep.2015.07.015)

Dovere L, Fera S, Grasso M, Lamberti D, Gargioli C, Muciaccia B, Lustri AM, Stefanini M \& Vicini E 2013 The niche-derived glial cell line-derived neurotrophic factor (GDNF) induces migration of mouse spermatogonial stem/progenitor cells. PLOS ONE 8 e59431. (https://doi. org/10.1371/journal.pone.0059431)

Ebata KT, Zhang X \& Nagano MC 2007 Male germ line stem cells have an altered potential to proliferate and differentiate during postnatal development in mice. Biology of Reproduction 76 841-847. (https://doi. org/10.1095/biolreprod.106.058305)

Endo T, Romer KA, Anderson EL, Baltus AE, de Rooij DG \& Page DC 2015 Periodic retinoic acid-STRA8 signaling intersects with periodic germ-cell competencies to regulate spermatogenesis. PNAS 112 E2347-E2356. (https://doi.org/10.1073/pnas.1505683112)

Endo T, Freinkman E, de Rooij DG \& Page DC 2017 Periodic production of retinoic acid by meiotic and somatic cells coordinates four transitions in mouse spermatogenesis. PNAS 114 E10132-E10141. (https://doi. org/10.1073/pnas.1710837114)

Ernst C, Eling N, Martinez-Jimenez CP, Marioni JC \& Odom DT 2019 Staged developmental mapping and $\mathrm{X}$ chromosome transcriptional dynamics during mouse spermatogenesis. Nature Communications 10 1251. (https://doi.org/10.1038/s41467-019-09182-1)

Faisal I, Cisneros-Montalvo S, Hamer G, Tuominen MM, Laurila PP, Tumiati M, Jauhiainen M, Kotaja N, Toppari J, Mäkelä JA et al. 2019 Transcription factor USF1 is required for maintenance of germline stem cells in male mice. Endocrinology 160 1119-1136. (https://doi. org/10.1210/en.2018-01088)

Falender AE, Freiman RN, Geles KG, Lo KC, Hwang K, Lamb DJ, Morris PL, Tjian R \& Richards JS 2005 Maintenance of spermatogenesis requires TAF4b, a gonad-specific subunit of TFIID. Genes and Development 19 794-803. (https://doi.org/10.1101/gad.1290105)

Filipponi D, Hobbs RM, Ottolenghi S, Rossi P, Jannini EA, Pandolfi PP \& Dolci S 2007 Repression of kit expression by Plzf in germ cells. Molecular and Cellular Biology 27 6770-6781. (https://doi.org/10.1128/ MCB.00479-07)

Fischer S, Kohlhase J, Bohm D, Schweiger B, Hoffmann D, Heitmann M, Horsthemke B \& Wieczorek D 2008 Biallelic loss of function of the promyelocytic leukaemia zinc finger (PLZF) gene causes severe skeletal defects and genital hypoplasia. Journal of Medical Genetics 45 731-737. (https://doi.org/10.1136/jmg.2008.059451)

Franca LR, Hess RA, Dufour JM, Hofmann MC \& Griswold MD 2016 The Sertoli cell: one hundred fifty years of beauty and plasticity. Andrology 4 189-212. (https://doi.org/10.1111/andr.12165)

Garbuzov A, Pech MF, Hasegawa K, Sukhwani M, Zhang RJ, Orwig KE \& Artandi SE 2018 Purification of GFRalpha1+ and GFRalpha1spermatogonial stem cells reveals a niche-dependent mechanism for fate determination. Stem Cell Reports 10 553-567. (https://doi.org/10.1016/j. stemcr.2017.12.009)

Garcia TX, Farmaha JK, Kow S \& Hofmann MC 2014 RBPJ in mouse Sertoli cells is required for proper regulation of the testis stem cell niche. Development 141 4468-4478. (https://doi.org/10.1242/dev.113969)

Garcia TX, Parekh P, Gandhi P, Sinha K \& Hofmann MC 2017 The NOTCH ligand JAG1 regulates GDNF expression in Sertoli cells. Stem Cells and Development 26 585-598. (https://doi.org/10.1089/scd.2016.0318)
Gely-Pernot A, Raverdeau M, Celebi C, Dennefeld C, Feret B, Klopfenstein M, Yoshida S, Ghyselinck NB \& Mark M 2012 Spermatogonia differentiation requires retinoic acid receptor gamma. Endocrinology 153 438-449. (https://doi.org/10.1210/en.2011-1102)

Goertz MJ, Wu Z, Gallardo TD, Hamra FK \& Castrillon DH 2011 FoxO1 is required in mouse spermatogonial stem cells for their maintenance and the initiation of spermatogenesis. Journal of Clinical Investigation $12 \mathbf{1}$ 3456-3466. (https://doi.org/10.1172/JCI57984)

Grasso M, Fuso A, Dovere L, de Rooij DG, Stefanini M, Boitani C \& Vicini E 2012 Distribution of GFRA1-expressing spermatogonia in adult mouse testis. Reproduction 143 325-332. (https://doi.org/10.1530/REP11-0385)

Griswold MD 2016 Spermatogenesis: the commitment to meiosis. Physiological Reviews 96 1-17. (https://doi.org/10.1152/physrev.00013.2015)

Hammoud SS, Low DH, Yi C, Carrell DT, Guccione E \& Cairns BR 2014 Chromatin and transcription transitions of mammalian adult germline stem cells and spermatogenesis. Cell Stem Cell 15 239-253. (https://doi. org/10.1016/j.stem.2014.04.006)

Hara K, Nakagawa T, Enomoto H, Suzuki M, Yamamoto M, Simons BD \& Yoshida S 2014 Mouse spermatogenic stem cells continually interconvert between equipotent singly isolated and syncytial states. Cell Stem Cell 14 658-672. (https://doi.org/10.1016/j.stem.2014.01.019)

Hasegawa K, Namekawa SH \& Saga Y 2013 MEK/ERK signaling directly and indirectly contributes to the cyclical self-renewal of spermatogonial stem cells. Stem Cells 31 2517-2527. (https://doi.org/10.1002/stem.1486)

Hasegawa K, Sin HS, Maezawa S, Broering TJ, Kartashov AV, Alavattam KG, Ichijima Y, Zhang F, Bacon WC, Greis KD et al. 2015 SCML2 establishes the male germline epigenome through regulation of histone H2A ubiquitination. Developmental Cell 32 574-588. (https:// doi.org/10.1016/j.devcel.2015.01.014)

Hata K, Okano M, Lei H \& Li E 2002 Dnmt3L cooperates with the Dnmt3 family of de novo DNA methyltransferases to establish maternal imprints in mice. Development 129 1983-1993.

Hata K, Kusumi M, Yokomine T, Li E \& Sasaki H 2006 Meiotic and epigenetic aberrations in Dnmt3L-deficient male germ cells. Molecular Reproduction and Development 73 116-122. (https://doi.org/10.1002/ mrd.20387)

He Z, Jiang J, Kokkinaki M, Golestaneh N, Hofmann MC \& Dym M 2008 Gdnf upregulates c-Fos transcription via the Ras/ERK1/2 pathway to promote mouse spermatogonial stem cell proliferation. Stem Cells 26 266-278. (https://doi.org/10.1634/stemcells.2007-0436)

Helsel AR, Yang QE, Oatley MJ, Lord T, Sablitzky F \& Oatley JM 2017 ID4 levels dictate the stem cell state in mouse spermatogonia. Development 144 624-634. (https://doi.org/10.1242/dev.146928)

Hermann BP, Cheng K, Singh A, Roa-De La Cruz L, Mutoji KN, Chen IC, Gildersleeve H, Lehle JD, Mayo M, Westernstroer B et al. 2018 The mammalian spermatogenesis single-cell transcriptome, from spermatogonial stem cells to spermatids. Cell Reports 25 1650-1667.e8. (https://doi.org/10.1016/j.celrep.2018.10.026)

Hilz S, Modzelewski AJ, Cohen PE \& Grimson A 2016 The roles of microRNAs and siRNAs in mammalian spermatogenesis. Development 143 3061-3073. (https://doi.org/10.1242/dev.136721)

Hobbs RM, Seandel M, Falciatori I, Rafii S \& Pandolfi PP 2010 Plzf regulates germline progenitor self-renewal by opposing mTORC1. Cell 142 468-479. (https://doi.org/10.1016/j.cell.2010.06.041)

Hobbs RM, Fagoonee S, Papa A, Webster K, Altruda F, Nishinakamura R, Chai L \& Pandolfi PP 2012 Functional antagonism between Sall4 and Plzf defines germline progenitors. Cell Stem Cell 10 284-298. (https:// doi.org/10.1016/j.stem.2012.02.004)

Hobbs RM, La HM, Makela JA, Kobayashi T, Noda T \& Pandolfi PP 2015 Distinct germline progenitor subsets defined through Tsc2-mTORC1 signaling. EMBO Reports 16 467-480. (https://doi.org/10.15252/ embr.201439379)

Hogarth CA, Arnold S, Kent T, Mitchell D, Isoherranen N \& Griswold MD 2015 Processive pulses of retinoic acid propel asynchronous and continuous murine sperm production. Biology of Reproduction 9237. (https://doi.org/10.1095/biolreprod.114.126326)

Hu YC, de Rooij DG \& Page DC 2013 Tumor suppressor gene Rb is required for self-renewal of spermatogonial stem cells in mice. PNAS 110 12685-12690. (https://doi.org/10.1073/pnas.1311548110) 
Huang YH, Chin CC, Ho HN, Chou CK, Shen CN, Kuo HC, Wu TJ, Wu YC, Hung YC, Chang CC et al. 2009 Pluripotency of mouse spermatogonial stem cells maintained by IGF-1-dependent pathway. FASEB Journal 23 2076-2087. (https://doi.org/10.1096/fj.08-121939)

Ikami K, Tokue M, Sugimoto R, Noda C, Kobayashi S, Hara K \& Yoshida S 2015 Hierarchical differentiation competence in response to retinoic acid ensures stem cell maintenance during mouse spermatogenesis. Development 142 1582-1592. (https://doi.org/10.1242/dev.118695)

Ishii K, Kanatsu-Shinohara M, Toyokuni S \& Shinohara T 2012 FGF2 mediates mouse spermatogonial stem cell self-renewal via upregulation of Etv5 and Bcl6b through MAP2K1 activation. Development 139 17341743. (https://doi.org/10.1242/dev.076539)

Iwamori N, Iwamori T \& Matzuk MM 2013 H3K27 Demethylase, JMJD3, regulates fragmentation of spermatogonial cysts. PLOS ONE 8 e72689. (https://doi.org/10.1371/journal.pone.0072689)

Kanatsu-Shinohara M, Ogonuki N, Inoue K, Miki H, Ogura A, Toyokuni S \& Shinohara T 2003 Long-term proliferation in culture and germline transmission of mouse male germline stem cells. Biology of Reproduction 69 612-616. (https://doi.org/10.1095/biolreprod.103.017012)

Kanatsu-Shinohara M, Miki H, Inoue K, Ogonuki N, Toyokuni S, Ogura A \& Shinohara T 2005 Long-term culture of mouse male germline stem cells under serum- or feeder-free conditions RID C-1358-2010. Biology of Reproduction 72 985-991. (https://doi.org/10.1095/ biolreprod.104.036400)

Kanatsu-Shinohara M, Inoue K, Takashima S, Takehashi M, Ogonuki N, Morimoto H, Nagasawa T, Ogura A \& Shinohara T 2012 Reconstitution of mouse spermatogonial stem cell niches in culture. Cell Stem Cell 11 567-578. (https://doi.org/10.1016/j.stem.2012.06.011)

Kaucher AV, Oatley MJ \& Oatley JM 2012 NEUROG3 is a critical downstream effector for STAT3-regulated differentiation of mammalian stem and progenitor spermatogonia. Biology of Reproduction 86 164, 1-164, 11. (https://doi.org/10.1095/biolreprod.111.097386)

Kitadate Y, Jorg DJ, Tokue M, Maruyama A, Ichikawa R, Tsuchiya S, Segi-Nishida E, Nakagawa T, Uchida A, Kimura-Yoshida C et al. 2019 Competition for mitogens regulates spermatogenic stem cell homeostasis in an open niche. Cell Stem Cell 24 79-92.e6. (https://doi.org/10.1016/j. stem.2018.11.013)

Klein AM, Nakagawa T, Ichikawa R, Yoshida S \& Simons BD 2010 Mouse germ line stem cells undergo rapid and stochastic turnover. Cell Stem Cell 7 214-224. (https://doi.org/10.1016/j.stem.2010.05.017)

Komai Y, Tanaka T, Tokuyama Y, Yanai H, Ohe S, Omachi T, Atsumi N, Yoshida N, Kumano K, Hisha $\mathbf{H}$ et al. 2014 Bmi1 expression in longterm germ stem cells. Scientific Reports 4 6175. (https://doi.org/10.1038/ srep06175)

Kubo N, Toh H, Shirane K, Shirakawa T, Kobayashi H, Sato T, Sone H, Sato Y, Tomizawa S, Tsurusaki Y et al. 2015 DNA methylation and gene expression dynamics during spermatogonial stem cell differentiation in the early postnatal mouse testis. BMC Genomics 16 624. (https://doi. org/10.1186/s12864-015-1833-5)

Kubota H, Avarbock MR \& Brinster RL 2004 Growth factors essential for self-renewal and expansion of mouse spermatogonial stem cells. PNAS 101 16489-16494. (https://doi.org/10.1073/pnas.0407063101)

La HM, Chan AL, Legrand JMD, Rossello FJ, Gangemi CG, Papa A, Cheng Q, Morand EF \& Hobbs RM 2018a GILZ-dependent modulation of mTORC1 regulates spermatogonial maintenance. Development 145. (https://doi.org/10.1242/dev.165324)

La HM, Makela JA, Chan AL, Rossello FJ, Nefzger CM, Legrand JMD, De Seram M, Polo JM \& Hobbs RM $2018 b$ Identification of dynamic undifferentiated cell states within the male germline. Nature Communications 9 2819. (https://doi.org/10.1038/s41467-018-04827-z)

Lambrot R, Lafleur C \& Kimmins S 2015 The histone demethylase KDM1A is essential for the maintenance and differentiation of spermatogonial stem cells and progenitors. FASEB Journal 29 4402-4416. (https://doi. org/10.1096/fj.14-267328)

Leblond CP \& Clermont Y 1952 Definition of the stages of the cycle of the seminiferous epithelium in the rat. Annals of the New York Academy of Sciences 55 548-573. (https://doi.org/10.1111/j.1749-6632.1952. tb26576.x)

Lee J, Kanatsu-Shinohara M, Inoue K, Ogonuki N, Miki H, Toyokuni S, Kimura T, Nakano T, Ogura A \& Shinohara T 2007 Akt mediates selfrenewal division of mouse spermatogonial stem cells. Development 134 1853-1859. (https://doi.org/10.1242/dev.003004)
Li L, Wang M, Wang M, Wu X, Geng L, Xue Y, Wei X, Jia Y \& Wu X 2016 A long non-coding RNA interacts with Gfra1 and maintains survival of mouse spermatogonial stem cells. Cell Death and Disease 7 e2140. (https://doi.org/10.1038/cddis.2016.24)

Liao J, Ng SH, Luk AC, Suen HC, Qian Y, Lee AWT, Tu J, Fung JCL, Tang NLS, Feng B et al. 2019 Revealing cellular and molecular transitions in neonatal germ cell differentiation using single cell RNA sequencing. Development 146 dev174953. (https://doi.org/10.1242/dev.174953)

Liu Y, Giannopoulou EG, Wen D, Falciatori I, Elemento O, Allis CD, Rafii S \& Seandel M 2016 Epigenetic profiles signify cell fate plasticity in unipotent spermatogonial stem and progenitor cells. Nature Communications 7 11275. (https://doi.org/10.1038/ncomms11275)

Liu T, Chen X, Li T, Li X, Lyu Y, Fan X, Zhang P \& Zeng W 2017 Histone methyltransferase SETDB1 maintains survival of mouse spermatogonial stem/progenitor cells via PTEN/AKT/FOXO1 pathway. Biochimica et Biophysica Acta: Gene Regulatory Mechanisms 1860 1094-1102. (https://doi.org/10.1016/j.bbagrm.2017.08.009)

Lord T \& Oatley JM 2017 A revised Asingle model to explain stem cell dynamics in the mouse male germline. Reproduction 154 R55-R64. (https://doi.org/10.1530/REP-17-0034)

Lord T, Oatley MJ \& Oatley JM 2018 Testicular architecture is critical for mediation of retinoic acid responsiveness by undifferentiated spermatogonial subtypes in the mouse. Stem Cell Reports 10 538-552. (https://doi.org/10.1016/j.stemcr.2018.01.003)

Lovasco LA, Gustafson EA, Seymour KA, de Rooij DG \& Freiman RN 2015 TAF4b is required for mouse spermatogonial stem cell development. Stem Cells 33 1267-1276. (https://doi.org/10.1002/stem.1914)

Lovelace DL, Gao Z, Mutoji K, Song YC, Ruan J \& Hermann BP 2016 The regulatory repertoire of PLZF and SALL4 in undifferentiated spermatogonia. Development 143 1893-1906. (https://doi.org/10.1242/ dev.132761)

Loveland KL, Klein B, PueschI D, Indumathy S, Bergmann M, Loveland BE, Hedger MP \& Schuppe HC 2017 Cytokines in male fertility and reproductive pathologies: immunoregulation and beyond. Frontiers in Endocrinology 8 307. (https://doi.org/10.3389/fendo.2017.00307)

MacLean G, Li H, Metzger D, Chambon P \& Petkovich M 2007 Apoptotic extinction of germ cells in testes of Cyp26b1 knockout mice. Endocrinology 148 4560-4567. (https://doi.org/10.1210/en.20070492)

Maezawa S, Hasegawa K, Yukawa M, Sakashita A, Alavattam KG, Andreassen PR, Vidal M, Koseki H, Barski A \& Namekawa SH 2017 Polycomb directs timely activation of germline genes in spermatogenesis. Genes and Development 31 1693-1703. (https://doi.org/10.1101/ gad.302000.117)

Maezawa S, Hasegawa K, Yukawa M, Kubo N, Sakashita A, Alavattam KG, Sin HS, Kartashov AV, Sasaki H, Barski A et al. 2018 Polycomb protein SCML2 facilitates $\mathrm{H} 3 \mathrm{~K} 27 \mathrm{me} 3$ to establish bivalent domains in the male germline. PNAS 115 4957-4962. (https://doi.org/10.1073/ pnas.1804512115)

Mäkelä JA \& Toppari J 2017 Spermatogenesis. In Endocrinology of the Testis and Male Reproduction, 1st ed., pp 1-39. Eds M Simoni \& I Huhtaniemi. Springer International Publishing. (https://doi.org/10.1007/978-3-31929456-8_13-1)

Mäkelä JA \& Toppari J 2018a Testis physiology: seminiferous cycle. In Encyclopedia of Reproduction, 2nd ed. Eds B Jégou \& MK Skinner. Academic Press. (https://doi.org/10.1016/B978-0-12-801238-3.645701)

Mäkelä JA \& Toppari J 2018b Testis physiology: spermatogenic cell syncytium. In Encyclopedia of Reproduction, 2nd ed. Eds B Jégou \& MK Skinner. Academic Press. (https://doi.org/10.1016/B978-0-12-8012383.64569-5)

Mäkelä JA, Koskenniemi JJ, Virtanen HE \& Toppari J 2019 Testis development. Endocrine Reviews 40 857-905. (https://doi.org/10.1210/ er.2018-00140)

Makela JA, Toppari J, Rivero-Muller A \& Ventela S 2014 Reconstruction of mouse testicular cellular microenvironments in long-term seminiferous tubule culture. PLOS ONE 9 e90088. (https://doi.org/10.1371/journal. pone.0090088)

Masaki K, Sakai M, Kuroki S, Jo JI, Hoshina K, Fujimori Y, Oka K, Amano T, Yamanaka T, Tachibana M et al. 2018 FGF2 has distinct molecular functions from GDNF in the mouse germline niche. Stem Cell Reports 10 1782-1792. (https://doi.org/10.1016/j.stemcr.2018.03.016) 
McLean DJ, Friel PJ, Pouchnik D \& Griswold MD 2002 Oligonucleotide microarray analysis of gene expression in follicle-stimulating hormonetreated rat Sertoli cells. Molecular Endocrinology 16 2780-2792. (https:// doi.org/10.1210/me.2002-0059)

Meng X, Lindahl M, Hyvonen ME, Parvinen M, de Rooij DG, Hess MW, Raatikainen-Ahokas A, Sainio K, Rauvala H, Lakso M et al. 2000 Regulation of cell fate decision of undifferentiated spermatogonia by GDNF. Science 287 1489-1493. (https://doi.org/10.1126/ science.287.5457.1489)

Morales C \& Griswold MD 1987 Retinol-induced stage synchronization in seminiferous tubules of the rat. Endocrinology 121 432-434. (https://doi. org/10.1210/endo-121-1-432)

Mullaney BP \& Skinner MK 1992 Basic fibroblast growth factor (bFGF) gene expression and protein production during pubertal development of the seminiferous tubule: follicle-stimulating hormone-induced Sertoli cell bFGF expression. Endocrinology 131 2928-2934. (https://doi. org/10.1210/endo.131.6.1446630)

Myrick DA, Christopher MA, Scott AM, Simon AK, Donlin-Asp PG, Kelly WG \& Katz DJ 2017 KDM1A/LSD1 regulates the differentiation and maintenance of spermatogonia in mice. PLOS ONE 12 e0177473. (https://doi.org/10.1371/journal.pone.0177473)

Nagano MC 2003 Homing efficiency and proliferation kinetics of male germ line stem cells following transplantation in mice. Biology of Reproduction 69 701-707. (https://doi.org/10.1095/biolreprod.103.016352)

Nagano M, Avarbock MR \& Brinster RL 1999 Pattern and kinetics of mouse donor spermatogonial stem cell colonization in recipient testes. Biology of Reproduction 60 1429-1436. (https://doi.org/10.1095/ biolreprod60.6.1429)

Nagano R, Tabata S, Nakanishi Y, Ohsako S, Kurohmaru M \& Hayashi Y 2000 Reproliferation and relocation of mouse male germ cells (gonocytes) during prespermatogenesis. Anatomical Record 258 210-220. (https:// doi.org/10.1002/(SICI)1097-0185(20000201)2 58:2<210::AIDAR10>3.0.CO;2-X)

Nakagawa T, Nabeshima Y \& Yoshida S 2007 Functional identification of the actual and potential stem cell compartments in mouse spermatogenesis. Developmental Cell 12 195-206. (https://doi. org/10.1016/j.devcel.2007.01.002)

Nakagawa T, Sharma M, Nabeshima Y, Braun RE \& Yoshida S 2010 Functional hierarchy and reversibility within the murine spermatogenic stem cell compartment. Science 328 62-67. (https://doi.org/10.1126/ science.1182868)

Naughton CK, Jain S, Strickland AM, Gupta A \& Milbrandt J 2006 Glial cell-line derived neurotrophic factor-mediated RET signaling regulates spermatogonial stem cell fate. Biology of Reproduction 74 314-321. (https://doi.org/10.1095/biolreprod.105.047365)

Niimi Y, Imai A, Nishimura H, Yui K, Kikuchi A, Koike H, Saga Y \& Suzuki A 2019 Essential role of mouse dead end1 in the maintenance of spermatogonia. Developmental Biology 445 103-112. (https://doi. org/10.1016/j.ydbio.2018.11.003)

Oatley JM, Avarbock MR \& Brinster RL 2007 Glial cell line-derived neurotrophic factor regulation of genes essential for self-renewal of mouse spermatogonial stem cells is dependent on Src family kinase signaling. Journal of Biological Chemistry 282 25842-25851. (https:// doi.org/10.1074/jbc.M703474200)

Oatley JM, Avarbock MR, Telaranta AI, Fearon DT \& Brinster RL 2006 Identifying genes important for spermatogonial stem cell self-renewal and survival. PNAS 103 9524-9529. (https://doi.org/10.1073/ pnas.0603332103)

Oatley JM, Oatley MJ, Avarbock MR, Tobias JW \& Brinster RL 2009 Colony stimulating factor 1 is an extrinsic stimulator of mouse spermatogonial stem cell self-renewal. Development 136 1191-1199. (https://doi. org/10.1242/dev.032243)

Oatley MJ, Kaucher AV, Racicot KE \& Oatley JM 2011 Inhibitor of DNA binding 4 is expressed selectively by single spermatogonia in the male germline and regulates the self-renewal of spermatogonial stem cells in mice. Biology of Reproduction 85 347-356. (https://doi.org/10.1095/ biolreprod.111.091330)

Oduwole OO, Peltoketo H, Poliandri A, Vengadabady L, Chrusciel M, Doroszko M, Samanta L, Owen L, Keevil B, Rahman NA et al. 2018 Constitutively active follicle-stimulating hormone receptor enables androgen-independent spermatogenesis. Journal of Clinical Investigation 128 1787-1792. (https://doi.org/10.1172/JCI96794)
O'Hara L \& Smith LB 2015 Androgen receptor roles in spermatogenesis and infertility. Best Practice and Research: Clinical Endocrinology and Metabolism 29 595-605. (https://doi.org/10.1016/j.beem.2015.04.006)

Pellegrini M, Filipponi D, Gori M, Barrios F, Lolicato F, Grimaldi P, Rossi P, Jannini EA, Geremia R \& Dolci S 2008 ATRA and KL promote differentiation toward the meiotic program of male germ cells. Cell Cycle 7 3878-3888. (https://doi.org/10.4161/cc.7.24.7262)

Potter SJ \& DeFalco T 2017 Role of the testis interstitial compartment in spermatogonial stem cell function. Reproduction 153 R151-R162. (https://doi.org/10.1530/REP-16-0588)

Pui HP \& Saga Y 2017 Gonocytes-to-spermatogonia transition initiates prior to birth in murine testes and it requires FGF signaling. Mechanisms of Development 144 125-139. (https://doi.org/10.1016/j. mod.2017.03.002)

Puri P, Phillips BT, Suzuki H, Orwig KE, Rajkovic A, Lapinski PE, King PD, Feng GS \& Walker WH 2014 The transition from stem cell to progenitor spermatogonia and male fertility requires the SHP2 protein tyrosine phosphatase. Stem Cells 32 741-753. (https://doi.org/10.1002/ stem.1572)

Raverdeau M, Gely-Pernot A, Feret B, Dennefeld C, Benoit G, Davidson I, Chambon P, Mark M \& Ghyselinck NB 2012 Retinoic acid induces Sertoli cell paracrine signals for spermatogonia differentiation but cell autonomously drives spermatocyte meiosis. PNAS 109 16582-16587. (https://doi.org/10.1073/pnas.1214936109)

Romero Y, Vuandaba M, Suarez P, Grey C, Calvel P, Conne B, Pearce D, de Massy B, Hummler E \& Nef S 2012 The glucocorticoid-induced leucine zipper (GILZ) is essential for spermatogonial survival and spermatogenesis. Sexual Development 6 169-177. (https://doi. org/10.1159/000338415)

Sada A, Suzuki A, Suzuki H \& Saga Y 2009 The RNA-binding protein NANOS2 is required to maintain murine spermatogonial stem cells. Science 325 1394-1398. (https://doi.org/10.1126/science.1172645)

Sada A, Hasegawa K, Pin PH \& Saga Y 2012 NANOS2 acts downstream of glial cell line-derived neurotrophic factor signaling to suppress differentiation of spermatogonial stem cells. Stem Cells 30 280-291. (https://doi.org/10.1002/stem.790)

Sakai M, Masaki K, Aiba S, Tone M \& Takashima S 2018 Expression dynamics of self-renewal factors for spermatogonial stem cells in the mouse testis. Journal of Reproduction and Development 64 267-275. (https://doi.org/10.1262/jrd.2018-015)

Schrans-Stassen BH, van de Kant HJ, de Rooij DG \& van Pelt AM 1999 Differential expression of c-kit in mouse undifferentiated and differentiating type A spermatogonia. Endocrinology 140 5894-5900. (https://doi.org/10.1210/endo.140.12.7172)

Sharma M \& Braun RE 2018 Cyclical expression of GDNF is required for spermatogonial stem cell homeostasis. Development 145 dev151555. (https://doi.org/10.1242/dev.151555)

Shinohara T, Orwig KE, Avarbock MR \& Brinster RL 2001 Remodeling of the postnatal mouse testis is accompanied by dramatic changes in stem cell number and niche accessibility. PNAS 98 6186-6191. (https://doi. org/10.1073/pnas.111158198)

Shirakawa T, Yaman-Deveci R, Tomizawa S-i, Kamizato Y, Nakajima K, Sone H, Sato Y, Sharif J, Yamashita A, Takada-Horisawa Y et al. 2013 An epigenetic switch is crucial for spermatogonia to exit the undifferentiated state toward a Kit-positive identity. Development 140 3565-3576. (https://doi.org/10.1242/dev.094045)

Simon L, Ekman GC, Tyagi G, Hess RA, Murphy KM \& Cooke PS 2007 Common and distinct factors regulate expression of mRNA for ETV5 and GDNF, Sertoli cell proteins essential for spermatogonial stem cell maintenance. Experimental Cell Research 313 3090-3099. (https://doi. org/10.1016/j.yexcr.2007.05.002)

Song HW \& Wilkinson MF 2014 Transcriptional control of spermatogonial maintenance and differentiation. Seminars in Cell and Developmental Biology 30 14-26. (https://doi.org/10.1016/j.semcdb.2014.02.005)

Sugimoto R, Nabeshima Y \& Yoshida S 2012 Retinoic acid metabolism links the periodical differentiation of germ cells with the cycle of Sertoli cells in mouse seminiferous epithelium. Mechanisms of Development 128 610-624. (https://doi.org/10.1016/j.mod.2011.12.003)

Tadokoro Y, Yomogida K, Ohta H, Tohda A \& Nishimune Y 2002 Homeostatic regulation of germinal stem cell proliferation by the GDNF/ FSH pathway. Mechanisms of Development 113 29-39. (https://doi. org/10.1016/S0925-4773(02)00004-7) 
Takase HM \& Nusse R 2016 Paracrine Wnt/beta-catenin signaling mediates proliferation of undifferentiated spermatogonia in the adult mouse testis. PNAS 113 E1489-E1497. (https://doi.org/10.1073/pnas.1601461113)

Takashima S, Kanatsu-Shinohara M, Tanaka T, Morimoto H, Inoue K, Ogonuki N, Jijiwa M, Takahashi M, Ogura A \& Shinohara T 2015 Functional differences between GDNF-dependent and FGF2-dependent mouse spermatogonial stem cell self-renewal. Stem Cell Reports 4489 502. (https://doi.org/10.1016/j.stemcr.2015.01.010)

Tanaka T, Kanatsu-Shinohara M, Lei Z, Rao CV \& Shinohara T 2016 The luteinizing hormone-testosterone pathway regulates mouse spermatogonial stem cell self-renewal by suppressing WNT5A expression in Sertoli cells. Stem Cell Reports 7 279-291. (https://doi.org/10.1016/j. stemcr.2016.07.005)

Tegelenbosch RA \& de Rooij DG 1993 A quantitative study of spermatogonial multiplication and stem cell renewal in the $\mathrm{C} 3 \mathrm{H} / 101$ F1 hybrid mouse. Mutation Research 290 193-200. (https://doi org/10.1016/0027-5107(93)90159-D)

Teletin M, Vernet N, Yu J, Klopfenstein M, Jones JW, Feret B, Kane MA, Ghyselinck NB \& Mark M 2019 Two functionally redundant sources of retinoic acid secure spermatogonia differentiation in the seminiferous epithelium. Development 146 dev170225. (https://doi.org/10.1242/ dev.170225)

Tokue M, Ikami K, Mizuno S, Takagi C, Miyagi A, Takada R, Noda C, Kitadate Y, Hara K, Mizuguchi H et al. 2017 SHISA6 confers resistance to differentiation-promoting $\mathrm{wnt} /$ beta-catenin signaling in mouse spermatogenic stem cells. Stem Cell Reports 8 561-575. (https://doi. org/10.1016/j.stemcr.2017.01.006)

Tomizawa SI, Kobayashi Y, Shirakawa T, Watanabe K, Mizoguchi K, Hoshi I, Nakajima K, Nakabayashi J, Singh S, Dahl A et al. 2018 Kmt2b conveys monovalent and bivalent $\mathrm{H} 3 \mathrm{~K} 4 \mathrm{me} 3$ in mouse spermatogonial stem cells at germline and embryonic promoters. Development 145 dev169102. (https://doi.org/10.1242/dev.169102)

Tong MH, Yang QE, Davis JC \& Griswold MD 2013 Retinol dehydrogenase 10 is indispensible for spermatogenesis in juvenile males. PNAS $\mathbf{1 1 0}$ 543-548. (https://doi.org/10.1073/pnas.1214883110)

Uchida A, Kishi K, Aiyama Y, Miura K, Takase HM, Suzuki H, KanaiAzuma M, Iwamori T, Kurohmaru M, Tsunekawa N et al. 2016 In vivo dynamics of GFRalpha1-positive spermatogonia stimulated by GDNF signals using a bead transplantation assay. Biochemical and Biophysical Research Communications 476 546-552. (https://doi.org/10.1016/j. bbrc.2016.05.160)

van den Driesche S, Sharpe RM, Saunders PT \& Mitchell RT 2014 Regulation of the germ stem cell niche as the foundation for adult spermatogenesis: a role for miRNAs? Seminars in Cell and Developmental Biology 2976 83. (https://doi.org/10.1016/j.semcdb.2014.04.006)

van Pelt AM \& de Rooij DG 1990 Synchronization of the seminiferous epithelium after vitamin A replacement in vitamin A-deficient mice. Biology of Reproduction 43 363-367. (https://doi.org/10.1095/ biolreprod43.3.363)

Vasiliauskaite L, Berrens RV, Ivanova I, Carrieri C, Reik W, Enright AJ \& O'Carroll D 2018 Defective germline reprogramming rewires the spermatogonial transcriptome. Nature Structural and Molecular Biology 25 394-404. (https://doi.org/10.1038/s41594-018-0058-0)

Ventela S, Come C, Makela JA, Hobbs RM, Mannermaa L, Kallajoki M Chan EK, Pandolfi PP, Toppari J \& Westermarck J 2012a CIP2A promotes proliferation of spermatogonial progenitor cells and spermatogenesis in mice. PLOS ONE 7 e33209. (https://doi.org/10.1371/journal. pone.0033209)
Ventela S, Makela JA, Kulmala J, Westermarck J \& Toppari J $2012 b$ Identification and regulation of a stage-specific stem cell niche enriched by Nanog-positive spermatogonial stem cells in the mouse testis. Stem Cells 30 1008-1020. (https://doi.org/10.1002/stem.1077)

Vernet N, Dennefeld C, Rochette-Egly C, Oulad-Abdelghani M, Chambon P, Ghyselinck NB \& Mark M 2006 Retinoic acid metabolism and signaling pathways in the adult and developing mouse testis. Endocrinology 147 96-110. (https://doi.org/10.1210/en.2005-0953)

Wang S, Wang X, Wu Y \& Han C 2015 IGF-1R signaling is essential for the proliferation of cultured mouse spermatogonial stem cells by promoting the G2/M progression of the cell cycle. Stem Cells and Development $\mathbf{2 4}$ 471-483. (https://doi.org/10.1089/scd.2014.0376)

Yang QE, Kim D, Kaucher A, Oatley MJ \& Oatley JM 2013a CXCL12-CXCR4 signaling is required for the maintenance of mouse spermatogonial stem cells. Journal of Cell Science 126 1009-1020. (https://doi.org/10.1242/ jcs.119826)

Yang Q-E, Racicot KE, Kaucher AV, Oatley MJ \& Oatley JM 2013b MicroRNAs 221 and 222 regulate the undifferentiated state in mammalian male germ cells. Development 140 280-290. (https://doi. org/10.1242/dev.087403)

Yeh JR, Zhang X \& Nagano MC 2012 Indirect effects of Wnt3a/beta-catenin signalling support mouse spermatogonial stem cells in vitro. PLOS ONE 7 e40002. (https://doi.org/10.1371/journal.pone.0040002)

Yoshida S 2012 Elucidating the identity and behavior of spermatogenic stem cells in the mouse testis. Reproduction 144 293-302. (https://doi. org/10.1530/REP-11-0320)

Yoshida S, Sukeno M \& Nabeshima Y 2007 A vasculature-associated niche for undifferentiated spermatogonia in the mouse testis. Science 317 1722-1726. (https://doi.org/10.1126/science.1144885)

Zhou Q, Li Y, Nie R, Friel P, Mitchell D, Evanoff RM, Pouchnik D, Banasik B, McCarrey JR, Small C et al. 2008 Expression of stimulated by retinoic acid gene 8 (Stra8) and maturation of murine gonocytes and spermatogonia induced by retinoic acid in vitro. Biology of Reproduction 78 537-545. (https://doi.org/10.1095/biolreprod.107.064337)

Zhou Z, Shirakawa T, Ohbo K, Sada A, Wu Q, Hasegawa K, Saba R \& Saga Y 2015 RNA binding protein Nanos2 organizes post-transcriptional buffering system to retain primitive state of mouse spermatogonial stem cells. Developmental Cell 34 96-107. (https://doi.org/10.1016/j. devcel.2015.05.014)

Zhou Z, Kawabe H, Suzuki A, Shinmyozu K \& Saga Y 2017 NEDD4 controls spermatogonial stem cell homeostasis and stress response by regulating messenger ribonucleoprotein complexes. Nature Communications 8 15662. (https://doi.org/10.1038/ncomms15662)

Zohni K, Zhang X, Tan SL, Chan P \& Nagano MC 2012 The efficiency of male fertility restoration is dependent on the recovery kinetics of spermatogonial stem cells after cytotoxic treatment with busulfan in mice. Human Reproduction 27 44-53. (https://doi.org/10.1093/humrep/ der357)

Received 7 September 2018

First decision 15 October 2018

Revised manuscript received 16 May 2019

Accepted 18 June 2019 